\title{
"Sizing" Heterogeneous Chemistry in the Conversion of Gaseous Dimethyl Sulfide to Atmospheric Particles
}

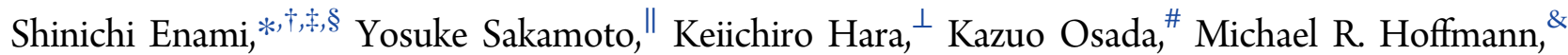
and Agustín J. Colussi*,\&

${ }^{\dagger}$ The Hakubi Center for Advanced Research, Kyoto University, Kyoto 606-8302, Japan

${ }^{\ddagger}$ Research Institute for Sustainable Humanosphere, Kyoto University, Uji 611-0011, Japan

${ }^{\S}$ PRESTO, Japan Science and Technology Agency, Kawaguchi 332-0012, Japan

"Faculty of Environmental Earth Science, Hokkaido University, Sapporo 060-0610, Japan

${ }^{\perp}$ Department of Earth Science System, Fukuoka University, Fukuoka 814-0180, Japan

${ }^{\#}$ Graduate School of Environmental Studies, Nagoya University, Nagoya 464-8601, Japan

${ }^{\&}$ Linde Center for Global Environmental Science, California Institute of Technology, California 91125, United States

Supporting Information

ABSTRACT: The oxidation of biogenic dimethyl sulfide (DMS) emissions is a global source of cloud condensation nuclei. The amounts of the nucleating $\mathrm{H}_{2} \mathrm{SO}_{4}(\mathrm{~g})$ species produced in such process, however, remain uncertain. Hydrophobic DMS is mostly oxidized in the gas phase into $\mathrm{H}_{2} \mathrm{SO}_{4}(\mathrm{~g})+$ DMSO(g) (dimethyl sulfoxide), whereas water-soluble DMSO is oxidized into $\mathrm{H}_{2} \mathrm{SO}_{4}(\mathrm{~g})$ in the gas phase and into $\mathrm{SO}_{4}{ }^{2-}+\mathrm{MeSO}_{3}{ }^{-}$(methanesulfonate) on water surfaces. $\mathrm{R}=\mathrm{MeSO}_{3}{ }^{-} /$(non-sea-salt $\mathrm{SO}_{4}{ }^{2-}$ ) ratios would therefore gauge both the strength of DMS sources and the extent of DMSO heterogeneous oxidation if $R_{\text {het }}=\mathrm{MeSO}_{3}{ }^{-} / \mathrm{SO}_{4}{ }^{2-}$ for $\mathrm{DMSO}(\mathrm{aq})+\cdot \mathrm{OH}(\mathrm{g})$ were known. Here, we report that $R_{\text {het }}=2.7$, a value obtained from online electrospray mass spectra of $\mathrm{DMSO}(\mathrm{aq})+\cdot \mathrm{OH}(\mathrm{g})$ reaction products that quantifies the $\mathrm{MeSO}_{3}{ }^{-}$produced in DMSO heterogeneous oxidation on aqueous aerosols for the first time. On this basis, the inverse $R$ dependence on particle radius in size-segregated aerosol collected over Syowa station and Southern oceans is shown to be consistent with the competition between DMSO gas-phase oxidation and its mass accommodation followed by oxidation on aqueous droplets. Geographical $R$ variations are thus associated with variable contributions of the heterogeneous pathway to DMSO atmospheric oxidation, which increase with the specific surface area of local aerosols.

\section{INTRODUCTION}

Aerosol particles affect climate both directly by scattering and absorbing solar radiation and indirectly as cloud condensation nuclei (CCN). CCN are generated from the gas-to-particle conversion of condensable species produced in the atmospheric processing of natural and anthropogenic gas emissions. A key condensable species, gaseous sulfuric acid, $\mathrm{H}_{2} \mathrm{SO}_{4}(\mathrm{~g})$, is produced in the oxidation of S-containing gases ${ }^{1,2}$ such as the biogenic dimethyl sulfide $\left((\mathrm{Me})_{2} \mathrm{~S}, \mathrm{DMS}\right)$ emitted (up to $45 \mathrm{~S} \mathrm{Tg}$ year $\left.^{-1}\right)^{3-5}$ by the ocean. The debate about whether enhanced $\mathrm{CCN}$ generation due to the stronger DMS emissions expected at higher temperatures would create a negative feedback to global warming (the CLAW conjecture) ${ }^{6}$ has underscored the fact that the strength of natural DMS emissions, their geographical and seasonal distributions, and, particularly, the chemistry involved in their atmospheric processing remain uncertain. ${ }^{4,5}$ Variations in the chemistry invoked by model estimates led to significant differences in predicted aerosol distributions and regional loads. ${ }^{7,8}$ The outstanding issue at present is how to quantify biogenic contributions to particle nucleation and growth from the composition of the aerosol. ${ }^{9-12}$ Lacking such information, models currently subsume the contribution of biogenic DMS to CCN into parameter optimization. ${ }^{8,10,13-20}$

The conversion of DMS into $\mathrm{H}_{2} \mathrm{SO}_{4}(\mathrm{~g})$ begins with its gasphase oxidation to $\mathrm{SO}_{2}$ en route to $\mathrm{H}_{2} \mathrm{SO}_{4}(\mathrm{~g})$ plus dimethyl sulfoxide $\left((\mathrm{Me})_{2} \mathrm{~S}=\mathrm{O}, \mathrm{DMSO}\right){ }^{2,21-23}$

$$
(\mathrm{Me})_{2} \mathrm{~S}(\mathrm{~g})+\cdot \mathrm{OH}(\mathrm{g})\left(+\mathrm{O}_{2}\right) \rightarrow(\mathrm{Me})_{2} \mathrm{~S}=\mathrm{O}(\mathrm{g})+\mathrm{HO}_{2} .
$$

$$
(\mathrm{Me})_{2} \mathrm{~S}(\mathrm{~g})+\cdot \mathrm{OH}(\mathrm{g})\left(+\mathrm{O}_{2}\right) \rightarrow \mathrm{CH}_{3} \mathrm{SCH}_{2} \mathrm{O}_{2} \cdot(\mathrm{g})+\mathrm{H}_{2} \mathrm{O}
$$

Received: October 29, 2015

Revised: January 12, 2016

Accepted: January 13, 2016

Published: January 13, 2016 


$$
\mathrm{CH}_{3} \mathrm{SCH}_{2} \mathrm{O}_{2} \cdot(\mathrm{g}) \rightarrow \rightarrow \mathrm{SO}_{2}(\mathrm{~g})
$$

The exceedingly large difference between Henry's law constants for DMS and DMSO dissolution in water: $H_{\text {DMS, WATER }}=0.45 \mathrm{M}$ atm $^{-1}$ versus $H_{\text {DMSO,WATER }} \approx 10^{7} \mathrm{M} \mathrm{atm}^{-1}, 22,24,25$ indicates that the oxidation of DMS will take place entirely in the gas phase, but hydrophilic and surface-active DMSO could be oxidized both in the gas phase and on the surface of aqueous atmospheric media, such as cloud, fog, and aerosol droplets. ${ }^{24}$ Significantly, the most recent laboratory studies indicate that the oxidation of DMSO by . OH-radicals in the gas phase exclusively yields $\mathrm{H}_{2} \mathrm{SO}_{4}(\mathrm{~g})$ via the $\mathrm{SO}_{2}(\mathrm{~g})$ produced in reaction $\mathrm{R} 4:^{26}$

$$
(\mathrm{Me})_{2} \mathrm{~S}=\mathrm{O}(\mathrm{g})+\cdot \mathrm{OH}(\mathrm{g}) \rightarrow \rightarrow \mathrm{SO}_{2}(\mathrm{~g})
$$

Therefore, the presence of methanesulfonate $\left(\mathrm{MeSO}_{3}{ }^{-}\right)$in the aerosol must be ascribed to the heterogeneous oxidation of $\operatorname{DMSO}(\mathrm{aq})$ by a yet-unidentified mechanism. In fact, the relevant process, i.e., the oxidation of $\mathrm{DMSO}(\mathrm{aq})$ by $\cdot \mathrm{OH}(\mathrm{g})$ at the air-water interface (reaction R5) has never been investigated before. $^{27}$

$$
(\mathrm{Me})_{2} \mathrm{~S}=\mathrm{O}(\text { interface, if })+\cdot \mathrm{OH}(\text { if }) \rightarrow \text { products(if) }
$$

In the field, numerous campaigns have reported that the $R=$ $\mathrm{MeSO}_{3}{ }^{-} / \mathrm{nss}^{-\mathrm{SO}_{4}}{ }^{2-}$ (nss = non-sea-salt) ratio generally increases at higher latitudes. This trend is more clearly apparent in the cleaner Southern hemisphere atmosphere, where anthropogenic contributions to aerosol nss- $\mathrm{SO}_{4}{ }^{2-}$ are significantly smaller than in its Northern counterpart. ${ }^{28,29}$ Such latitudinal $R$ variations have been generally attributed to the temperature dependence of the branching ratio of $\cdot \mathrm{OH}$ addition versus $\mathrm{H}$ abstraction DMS oxidation channels ( reactions $\mathrm{R} 1$ and $\mathrm{R} 2$ ), which ultimately lead to $\mathrm{DMSO}(\mathrm{g})$ and $\mathrm{H}_{2} \mathrm{SO}_{4}(\mathrm{~g})$, respectively. However, it should be realized that if that were the case, $\mathrm{nss}-\mathrm{SO}_{4}{ }^{2-}$ production should be temperature-independent because, as it is now known, ${ }^{26}$ the gas-phase oxidation of $\mathrm{DMSO}(\mathrm{g})$ yields $\mathrm{H}_{2} \mathrm{SO}_{4}(\mathrm{~g})$ exclusively, and therefore, all DMS would be always oxidized to $\mathrm{H}_{2} \mathrm{SO}_{4}(\mathrm{~g})$ at any temperature. In fact, the most recent interhemispheric measurements have failed to reveal a meaningful correlation of $R$ with air temperature. ${ }^{30}$ The same study correctly pointed out that the -5 to $0{ }^{\circ} \mathrm{C}$ temperature variations measured in the field could only have modest effects on reaction rates and, therefore, could not account for $R$ values spanning a 0.02 to 0.9 range. ${ }^{30}$ Temperature variations can neither account for the fact that $R$ is 3 to 10 times higher in coastal Antarctica than over the much colder Antarctic plateau. ${ }^{30}$ It is apparent that the uncertain chemical fate of DMS prevents a realistic representation of biogenic contributions to aerosol generation in atmospheric models. ${ }^{22,31-33}$ In fact, the consensus is that "there is still significant uncertainty about the end products of the DMS addition pathway" ${ }^{20}$ Previous campaign studies have acknowledged that molar $\mathrm{R}=\mathrm{MeSO}_{3}{ }^{-} / \mathrm{nss}^{-} \mathrm{SO}_{4}{ }^{2-}$ ratios "could be only partially explained by known DMS oxidation mechanisms", ${ }^{34}$ and that "the presence of $\mathrm{CH}_{3} \mathrm{SO}_{3}{ }^{-}$in sea salt particles indicates substantial formation and fast uptake of $\mathrm{CH}_{3} \mathrm{SO}_{3} \mathrm{H}$ by activated droplets containing sea salt, presumably resulting from the oxygen addition channel in the DMS oxidation mechanism" ${ }^{35}$ Note that the latter assertion implicitly assumes that $\mathrm{MeSO}_{3} \mathrm{H}$ is exclusively produced in the gas phase, at variance with updated chemistry, as noted above. ${ }^{26}$

Not surprisingly, it has long been conjectured that heterogeneous chemistry should play an important role in DMSO oxidation. ${ }^{22}$ Note that, given that DMSO reactions with $\mathrm{O}_{3}$ and $\mathrm{H}_{2} \mathrm{O}_{2}$ in bulk water are much slower than those with $\cdot \mathrm{OH}$ radicals: $k_{\left(\mathrm{DMSO}+\mathrm{O}_{3}\right) \mathrm{aq}} \approx 6 \mathrm{M}^{-1} \mathrm{~s}^{-1}, k_{\left(\mathrm{DMSO}+\mathrm{H}_{2} \mathrm{O}_{2}\right) \mathrm{aq}}<4.5 \times 10^{-5}$ $\mathrm{M}^{-1} \mathrm{~s}^{-1}, k_{(\mathrm{DMSO}+\mathrm{OH}) \mathrm{aq}}=4.5 \times 10^{9} \mathrm{M}^{-1} \mathrm{~s}^{-1}, 22,26,29,36-38 \mathrm{DMSO}$ in aqueous media is mostly oxidized by $\cdot \mathrm{OH}$ radicals. Furthermore, because DMSO is strongly enriched at the surface of water, ${ }^{39-44}$ its heterogeneous oxidation should be dominated by reactions with gas-phase $\cdot \mathrm{OH}(\mathrm{g})$ radicals. $^{40,43}$ We have previously shown that many chemical reactions at the air-water interface proceed faster and sometimes along different mechanisms than the corresponding processes in bulk water. ${ }^{45-49}$

Herein, we address these issues by performing experiments specifically designed to determine the $R_{\text {het }}=\mathrm{MeSO}_{3}{ }^{-} / \mathrm{SO}_{4}{ }^{2-}$ ratio in the oxidation of $\mathrm{DMSO}(\mathrm{aq})$ by $\cdot \mathrm{OH}(\mathrm{g})$ at the air-water interface. The results thus obtained are then applied to interpret extensive data on the composition of size-segregated aerosol collected over the Japanese Syowa station in Antarctica and over Southern oceans in ship cruises covering trajectories joining Cape Town (South Africa) with Freemantle (Western Australia).

\section{MATERIALS AND METHODS}

Laboratory Experiments. The experimental setup has been thoroughly described in previous publications, which should be perused for further details as needed. ${ }^{51,52}$ We summarize the specific features relevant to the experiments reported herein. In our experiments, we record online electrospray (ES) mass spectra of aqueous DMSO microjets exposed to trains of $\cdot \mathrm{OH}(\mathrm{g})$ pulses generated in situ via $266 \mathrm{~nm}$ laser flash photolysis of $\left(\mathrm{O}_{3}+\right.$ $\mathrm{H}_{2} \mathrm{O}+\mathrm{O}_{2}$ ) gas mixtures. Microjets are generated by pumping $\left(100 \mu \mathrm{L} \mathrm{min}{ }^{-1}\right)$ aqueous DMSO solutions into the spraying chamber of the mass spectrometer (Agilent 6130 Quadrupole LC/MS Electrospray System at Kyoto University) through a grounded stainless steel needle $(100 \mu \mathrm{m}$ bore $)$ coaxial with a sheath issuing high speed $(\sim 160 \mathrm{~m} / \mathrm{s})$ nebulizer $\mathrm{N}_{2}$ gas. ${ }^{53} \mathrm{~A}$ schematic diagram of the experimental setup is shown in Figure S1. Ions detected by ES mass spectrometry correspond to ions already present in the injected solution or those formed from the protonation or deprotonation of neutral reactants and products. We checked that the detected products ensue from the photolysis of $\mathrm{O}_{3}(\mathrm{~g})$, as shown in Figure S2 (see below), rather than from laser photolysis of dissolved DMSO. The surface specificity of the ES mass spectra acquired in these experiments has been validated as described in previous publications. $^{46,47,49,53-58}$

In our experiments, exposures $E(E=\cdot \mathrm{OH}$ concentration $\times$ time) to $0.2-50 \mathrm{ppmv}=5 \times 10^{12} \sim 1 \times 10^{15} \cdot \mathrm{OH}$ molecules $\mathrm{cm}^{-3}$ (at $1 \mathrm{~atm}, 298 \mathrm{~K}$ ) for $10 \mu \mathrm{s}$ : $E=2.5 \times 10^{7}-1.2 \times 10^{10}$ molecules $\mathrm{cm}^{-3} \mathrm{~s}$ are significantly smaller than those prevalent in typical flow reactor studies, $E \geq 2 \times 10^{10}$ molecules $\mathrm{cm}^{-3} \mathrm{s.}^{59-61}$ Note that because $\mathrm{MeSO}_{3}{ }^{-}$and $\mathrm{SO}_{4}{ }^{2-}$ products are demonstrably inert to $\cdot \mathrm{OH}$ (see Figure $\mathrm{S} 3$ and $\mathrm{S} 4$ ), excess $\cdot \mathrm{OH}$ would not affect their relative yields (see below). We wish to point out that $[\cdot \mathrm{OH}]$ at the surface of microjets are likely lower than the $[\mathrm{OH}(\mathrm{g})]_{0}$ estimated at the laser photolysis spot due to partial losses via gasphase $\cdot \mathrm{OH}$ recombination into nonreactive $\mathrm{H}_{2} \mathrm{O}_{2}$. Hence, we consider that $[\cdot \mathrm{OH}(\mathrm{g})]_{0}$ values are upper limits to $[\cdot \mathrm{OH}]$ on the surface of microjets. $\cdot \mathrm{OH}(\mathrm{g})$ losses via reaction with $\mathrm{O}_{3}(\mathrm{~g})$ $\left(k_{\mathrm{O}_{3}+\mathrm{OH}}=7.3 \times 10^{-14} \mathrm{~cm}^{3} \text { molecule }{ }^{-1} \mathrm{~s}^{-1}\right)^{62}$ have half-lives $\tau_{1 / 2}>$ $500 \mu$ s that are much longer than the $\leq 3 \mu$ s transit times $\cdot \mathrm{OH}(\mathrm{g})$ takes to travel the $\leq 1 \mathrm{~mm}$ distance separating the laser focal point from the microjet surface. Because the thermal accommodation coefficient of $\cdot \mathrm{OH}$ on water approaches unity: $S \sim 0.95,{ }^{63}$. $\mathrm{OH}(\mathrm{g})$ initially sticks to the surface of microjets ${ }^{60,64}$ and then 
reacts with sparse DMSO at the air-water interface (R5) or recombine into $\mathrm{H}_{2} \mathrm{O}_{2}$ (R6).

$$
\cdot \mathrm{OH}(\text { if })+\cdot \mathrm{OH}(\text { if }) \rightarrow \mathrm{H}_{2} \mathrm{O}_{2}
$$

The reported affinity of $\cdot \mathrm{OH}$ radicals for aqueous interfacial layers $^{63,65}$ and its diffusionally controlled rate constants in water, $k_{\mathrm{DMSO}_{+} \cdot \mathrm{OH}}=4.5 \times 10^{9} \mathrm{M}^{-1} \mathrm{~s}^{-1}$ and $k_{\cdot \mathrm{OH}+\mathrm{OH}}=5.5 \times 10^{9} \mathrm{M}^{-1}$ $\mathrm{s}^{-1}, 38,66$ ensure that R5 and R6 proceed at the air-water rather in bulk solution.

Field Measurements. Details of the observatory, aerosol inlet, and tubing for aerosol ground measurements at Syowa Station, Antarctica have been previously described by Osada et al. ${ }^{67}$ Aerosol samples were collected using a two-stage midvolume impactor (MVI) and back-up filter for bulk analysis following the same procedure as described by Hara et al. ${ }^{68}$ Cutoff diameters are 2.0 and $0.2 \mu \mathrm{m}$. To avoid the intake of locally contaminated air, we operated MVI samplings when the wind blew from the clean-air sector. Considering that aerosol sampling was carried out inside the room, aerosol particles were actually collected on the filter at room temperature, ca. $20{ }^{\circ} \mathrm{C}$. After sampling was completed, each filter was placed immediately into polypropylene $15 \mathrm{~mL}$ centrifuge vials fitted with airtight caps to prevent contamination during sample storage. Sample vials were packed in polyethylene bags and were kept at about $-20{ }^{\circ} \mathrm{C}$ in a freezer until chemical analysis in Japan. For a qualitative check of the samples, procedural blank samples were taken from each sampler periodically (twice a month).

On board of the Umitaka-maru vessel, the aerosol sampler (three-stage midvolume impactor and back-up filter) was placed inside a weather shield located on the uppermost deck of the ship. Cut-off aerosol diameters were 6.0, 2.0, and $0.2 \mu \mathrm{m}$. To avoid contamination from ship exhaust, we controlled aerosol samplings by a wind-selector, which activated sampling only when the wind direction faced forward and wind speeds exceeded $2 \mathrm{~m} \mathrm{sec}^{-1}$.

Sample analyses were performed after extracting the watersoluble constituents of aerosol particles with ultrapure water (14 $\mathrm{mL}$ per sample, 18.3 M , Milli-Q water). Concentrations of the water-soluble constituents were determined with an ionchromatography (Dionex, DX-120) using a $500 \mathrm{~mL}$ injection loop for each flow system, equipped with an AS11A analytical column and an AG11 guard column for anion separation (eluent flowing at $2 \mathrm{~mL} \mathrm{~min}^{-1}$ : Milli-Q water, $5 \mathrm{mM}$ and $100 \mathrm{mM} \mathrm{NaOH}$ with gradient elution), and a CS12 analytical column and CG12 guard column for cation separation (eluent flowing at $1 \mathrm{~mL}$ $\mathrm{min}^{-1}: 20 \mathrm{mM} \mathrm{MSA}$ ). The amounts of sea-salt (ss) $\mathrm{SO}_{4}{ }^{2-}$ contained in the aerosol were calculated from measured $\mathrm{Na}^{+}$ concentrations by assuming the ss- $\mathrm{SO}_{4}{ }^{2-} / \mathrm{Na}^{+}=0.0602$ molar ratio in bulk seawater for the aerosol collected throughout, except at Syowa station during winter months, in which case the ss$\mathrm{SO}_{4}{ }^{2-} / \mathrm{Na}^{+}=0.02$ value applied. ${ }^{69}$

\section{RESULTS AND DISCUSSION}

Product Distribution in the DMSO(aq) $+\cdot \mathrm{OH}(\mathrm{g})$ Reaction. Figure 1 shows a typical positive-ion ES mass spectrum of aqueous $1 \mathrm{mM}$ DMSO microjets (previously acidified with $\mathrm{HCl}$ to $\mathrm{pH} 1.1)$ exposed to $\mathrm{O}_{2}(\mathrm{~g}) / \mathrm{H}_{2} \mathrm{O}(\mathrm{g}) / \mathrm{N}_{2}(\mathrm{~g})$ or $\mathrm{O}_{3}(\mathrm{~g}) / \mathrm{O}_{2}(\mathrm{~g}) / \mathrm{H}_{2} \mathrm{O}(\mathrm{g}) / \mathrm{N}_{2}(\mathrm{~g})$ mixtures, both in the dark and under $266 \mathrm{~nm}$ laser pulses. In Figure $1 \mathrm{~A}$, the $\mathrm{m} / \mathrm{z}^{+}=79$ and $\mathrm{m} / \mathrm{z}^{+}$ $=95$ signals are readily assigned to $\mathrm{DMSOH}^{+}$and to the protonated ion $\mathrm{DMSO}_{2} \mathrm{H}^{+}$of the dimethyl sulfone produced under $\mathrm{O}_{3}(\mathrm{~g})$ in the dark, respectively. The fact that $\sim 10 \%$ $\mathrm{DMSO}(\mathrm{aq})$ is oxidized into $\mathrm{DMSO}_{2}$ by $160 \mathrm{ppmv} \mathrm{O}_{3}(\mathrm{~g})$ within
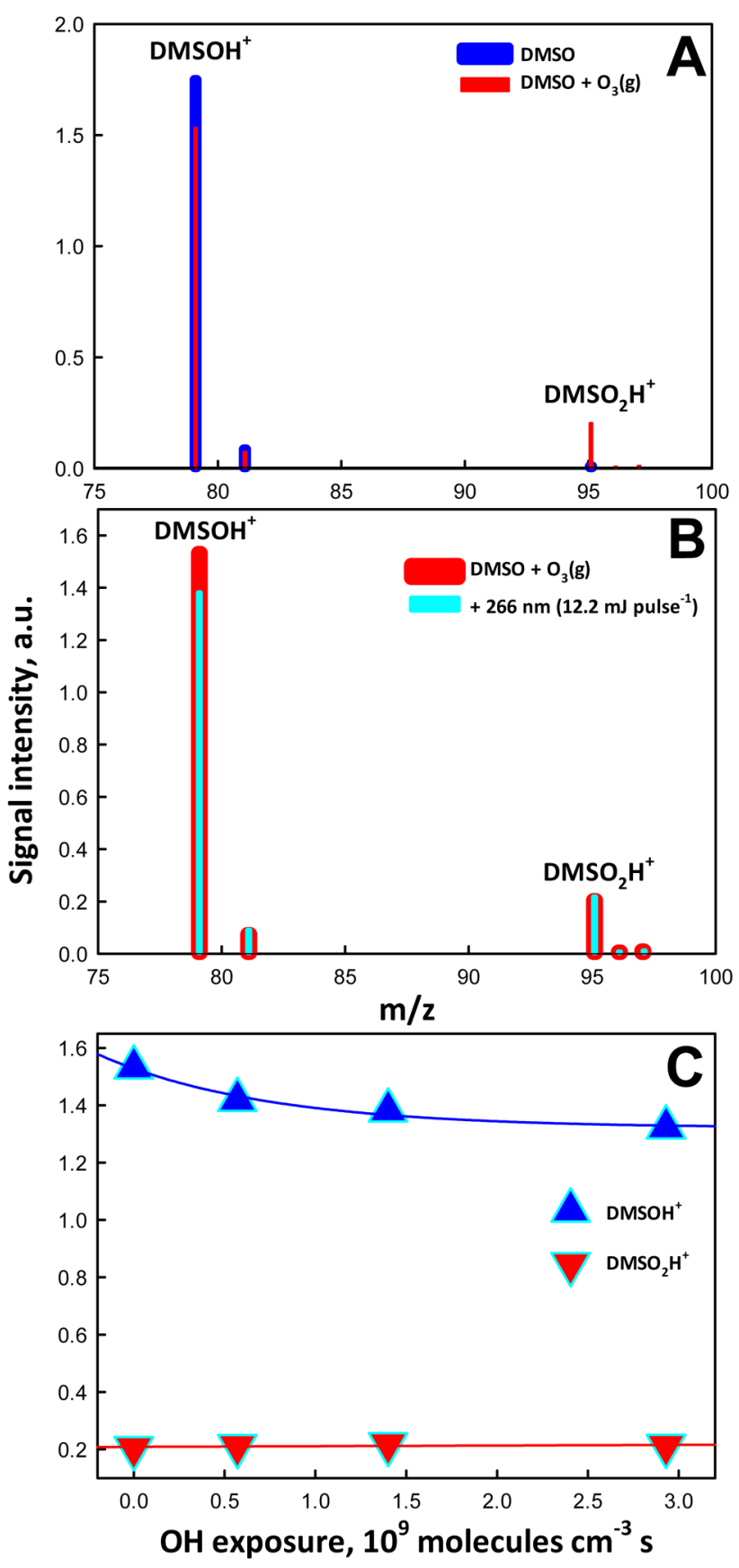

Figure 1. Positive-ion mass spectra of $1 \mathrm{mM} \mathrm{DMSO}$ at $\mathrm{pH} 1.1$ (A) in the absence (blue) and presence (red) of $160 \mathrm{ppmv} \mathrm{O}_{3}(\mathrm{~g})$ in $\mathrm{O}_{2}(\mathrm{~g}) /$ $\mathrm{H}_{2} \mathrm{O}(\mathrm{g}) / \mathrm{N}_{2}(\mathrm{~g})$ mixtures and $(\mathrm{B})$ in the presence of 160 ppmv $\mathrm{O}_{3}(\mathrm{~g})$ (red) and under simultaneous $266 \mathrm{~nm}$ irradiation (light blue); [. $\mathrm{OH}(\mathrm{g})]_{0} \leq 5.7$ ppmv. (C) Signal intensities of $\mathrm{m} / z=79\left(\mathrm{DMSOH}^{+}\right)$ and $95\left(\mathrm{DMSO}_{2} \mathrm{H}^{+}\right)$as functions of $\cdot \mathrm{OH}(\mathrm{g})$ exposure. All experiments at $1 \mathrm{~atm}$ and $298 \mathrm{~K}$. Lines are single exponential (blue) and linear (red) regression curves.

$<50 \mu \mathrm{s}$ is in itself a remarkable observation. The reason is that if the reaction had taken place in bulk water, with $k_{\mathrm{DMSO}+\mathrm{O}_{3}} \sim 6 \mathrm{M}^{-1}$ $\mathrm{s}^{-1},{ }^{70-72}\left[\mathrm{O}_{3}(\mathrm{aq})\right] \leq 1.6 \mu \mathrm{M}=\mathrm{H} \times \mathrm{P}\left(\mathrm{O}_{3}(\mathrm{~g})\right)\left(\mathrm{H}=0.01 \mathrm{M} \mathrm{atm}^{-1}\right.$ is Henry's law constant for $\mathrm{O}_{3}$ in water at $298 \mathrm{~K},{ }^{21} \mathrm{P}\left(\mathrm{O}_{3}(\mathrm{~g})\right)=$ $\left.160 \mathrm{ppmv}=1.6 \times 10^{-4} \mathrm{~atm}\right)$, negligible amounts of DMSO would have been consumed in $<50 \mu \mathrm{s}$ contact times. Thus, the interfacial ozonation of DMSO is orders of magnitude faster than in bulk water. We have previously observed similar rate 
Scheme 1. Mechanism of the $\cdot \mathrm{OH}$-Initiated Oxidation of DMSO at the Air-Water Interface

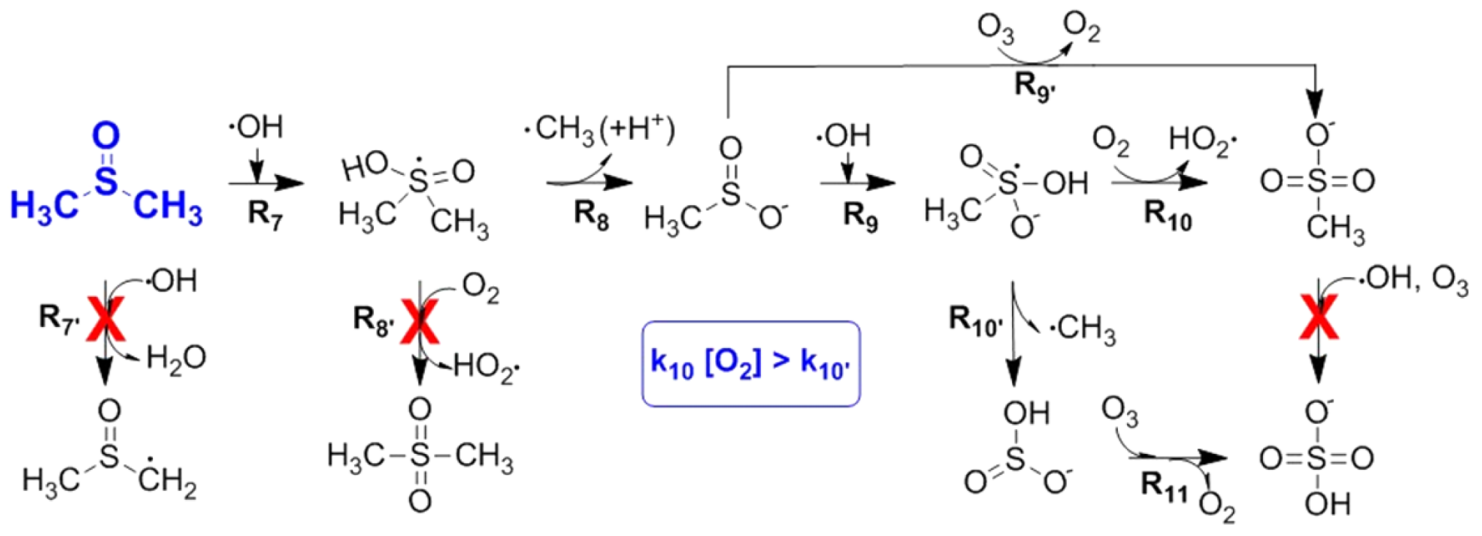

enhancements for interfacial $\mathrm{O}$ atom transfers from $\mathrm{O}_{3}$ relative to those in bulk water, ${ }^{46,73-76}$ for example, in the $\mathrm{Fe}^{2+}+\mathrm{O}_{3}$ reaction at the air-water interface. ${ }^{49}$ It is apparent that interfacial water is a unique reaction medium, ${ }^{45,49,74,75}$ quite different from bulk gas or liquid phases. ${ }^{59,77,78}$

Upon laser irradiation of the $\left[\mathrm{O}_{3}(\mathrm{~g})+\mathrm{H}_{2} \mathrm{O}(\mathrm{g})\right]$ mixtures, $\mathrm{DMSOH}^{+}$decreases further, while $\mathrm{DMSO}_{2} \mathrm{H}^{+}$remains unchanged (Figure 1B). We experimentally confirmed that $\mathrm{DMSO}$ (aq) is not photolyzed at $266 \mathrm{~nm}$ and, in the absence of $\mathrm{O}_{3}(\mathrm{~g}), \mathrm{m} / z^{+}=79$ signals are unaffected by $266 \mathrm{~nm}$ pulses under the present experimental conditions (Figure S2).

On the basis of these observations, we infer that (1) $\mathrm{O}_{3}(\mathrm{~g})$ oxidizes $\mathrm{DMSO}(\mathrm{aq})$ into $\mathrm{DMSO}_{2}$ via direct $\mathrm{O}$-atom transfer, whereas $(2)$ the $\cdot \mathrm{OH}(\mathrm{g})$ produced in the photolysis of $\left[\mathrm{O}_{3}(\mathrm{~g})+\right.$ $\left.\mathrm{H}_{2} \mathrm{O}(\mathrm{g})\right]$ mixtures reacts with $\mathrm{DMSO}(\mathrm{aq})$ to produce different species. ${ }^{66}$ The absence of positive ions other than $m / z^{+}=79$ and $m / z^{+}=95$ under $\left[\mathrm{O}_{3}(\mathrm{~g})+\mathrm{H}_{2} \mathrm{O}(\mathrm{g})+266 \mathrm{~nm}\right.$ radiation $]$ indicates that the new species are strong acids, which would appear as anions, or neutrals that could not be protonated. This observation excludes, for example, $\mathrm{H}$-atom abstraction by $\cdot \mathrm{OH}$ from DMSO methyl groups, reaction $\mathrm{R}_{7^{\prime}}$ in Scheme 1, because it would have led to $\mathrm{CH}_{3} \mathrm{SO}\left(\mathrm{H}^{+}\right) \mathrm{CH}_{2} \mathrm{O}_{2} \cdot\left(\mathrm{m} / z^{+}=110\right)$ signals (not detected) under excess $\mathrm{O}_{2}$ or the alcohols and aldehydes that would ensue for $\mathrm{CH}_{3} \mathrm{SOCH}_{2} \mathrm{O}_{2}$. self-reactions. ${ }^{21,51,52}$

The fact that $\mathrm{DMSO}_{2}$ is not produced in the oxidation of DMSO by $\cdot \mathrm{OH}$ implies that the DMS $(\cdot) \mathrm{O}-\mathrm{OH}$ adduct formed in reaction $\mathrm{R}_{7}$ rapidly splits $\cdot \mathrm{CH}_{3}$ (reaction $\mathrm{R}_{8}$ ) rather than react with $\mathrm{O}_{2}$ (reaction $\left.\mathrm{R}_{8^{\prime}}\right)$ under present conditions $\left(\left[\mathrm{O}_{2}(\mathrm{~g})\right]=2.1 \times\right.$ $10^{18}$ molecules $\left.\mathrm{cm}^{-3}\right){ }^{21,26,79,80}$ The reported negative activation energy for the DMSO $+\cdot \mathrm{OH}$ reaction in both gas and liquid phase ${ }^{29,81}$ supports the formation of a DMS $(\cdot) \mathrm{O}-\mathrm{OH}$ adduct in $\mathrm{R}_{7}$ via the addition of $\cdot \mathrm{OH}$ to the $\mathrm{S}$-atom of pyramidal DMSO. ${ }^{39,82-84}$ The lack of $\mathrm{DMSO}_{2}$ formation from the $\mathrm{DMSO}(\mathrm{aq})+\cdot \mathrm{OH}(\mathrm{g})$ reaction in our experiments is in line with related experiments in bulk water ${ }^{66}$ but in contrast with the $20-30 \%$ yields of $\mathrm{DMSO}_{2}$ reported in the gas phase. ${ }^{79}$ It appears that water catalyzes the decomposition of chemically activated DMS $(\cdot) \mathrm{O}-\mathrm{OH}^{*}$ formed in $\mathrm{R}_{7} \cdot{ }^{85}$ Note that because $\mathrm{DMSO}_{2}$ does not react with $\cdot \mathrm{OH}$, in accordance with literature reports, if it had been produced (in reaction $\mathrm{R}_{8^{\prime}}$ ) it should have been detected. $^{29}$

Figure 2 shows a negative-ion ES mass spectrum of aqueous 1 $\mathrm{mM}$ DMSO microjets at $\mathrm{pH} \sim 7$ exposed to $\mathrm{O}_{2}(\mathrm{~g}) / \mathrm{H}_{2} \mathrm{O}(\mathrm{g}) /$ $\mathrm{N}_{2}(\mathrm{~g})$ or $\mathrm{O}_{3}(\mathrm{~g}) / \mathrm{O}_{2}(\mathrm{~g}) / \mathrm{H}_{2} \mathrm{O}(\mathrm{g}) / \mathrm{N}_{2}(\mathrm{~g})$ mixtures both in the dark and under $266 \mathrm{~nm}$ laser pulses, which is more informative about the products ensuing reaction $R_{7}$. The $m / z^{-}=79,95$, and

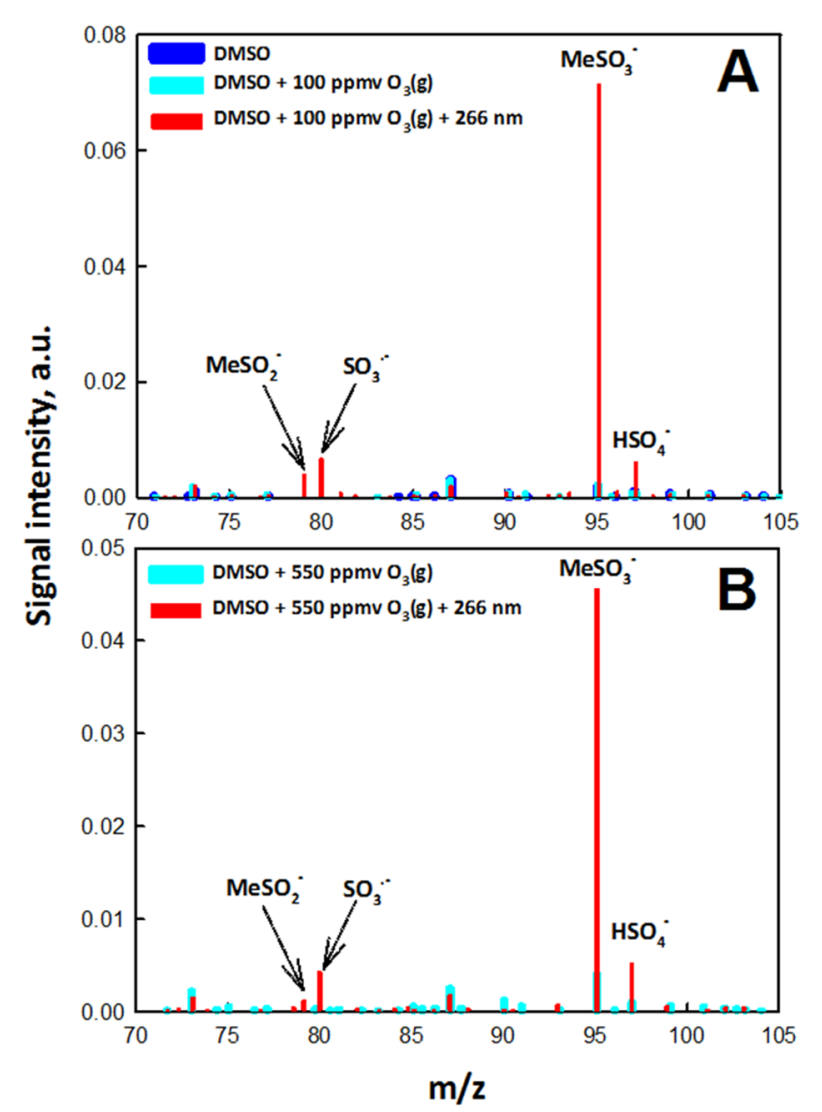

Figure 2. Negative-ion mass spectra (background subtracted) of $1 \mathrm{mM}$ DMSO at $\mathrm{pH} \sim 7$ without $\mathrm{O}_{3}$ (blue) or with $\mathrm{O}_{3}$ in $\mathrm{O}_{2}(\mathrm{~g}) / \mathrm{H}_{2} \mathrm{O}(\mathrm{g}) /$ $\mathrm{N}_{2}(\mathrm{~g})$ mixtures at $1 \mathrm{~atm}$ and $298 \mathrm{~K}$ in the absence (light blue) and presence (red) of $266 \mathrm{~nm}$ radiation. (A) $\left[\mathrm{O}_{3}(\mathrm{~g})\right]=100 \mathrm{ppmv},[$. $\mathrm{OH}(\mathrm{g})]_{0} \leq 10$ ppmv. (B) $\left[\mathrm{O}_{3(\mathrm{~g})}\right]=550 \mathrm{ppmv},[\cdot \mathrm{OH}(\mathrm{g})]_{0} \leq 50 \mathrm{ppmv}$.

97 signals are readily assigned to methane sulfinate $\left(\mathrm{MeSO}_{2}{ }^{-}\right)$, $\mathrm{MeSO}_{3}{ }^{-}$and bisulfate $\left(\mathrm{HSO}_{4}{ }^{-}\right)$, respectively. The $\mathrm{m} / z^{-}=80$ signal is assigned to the $\mathrm{SO}_{3}^{--}$fragment of the collisionally induced dissociation of $\mathrm{MeSO}_{3}{ }^{-}$rather than the $\mathrm{S}_{2} \mathrm{O}_{6}{ }^{2-}$ dianion product, an assertion based on the anticorrelation of $m / z^{-}=80$ versus $m / z^{-}=95$ signal intensities as functions of fragmentation voltage (Figure S5). The absence of a detectable $m / z^{-}=81$ signal corresponding to $\mathrm{HSO}_{3}{ }^{-}$implies either that reaction $\mathrm{R}_{10^{\prime}}$ is slower than reaction $\mathrm{R}_{10}$ or that $\mathrm{HSO}_{3}{ }^{-}$is rapidly oxidized by $\mathrm{O}_{3}$ into $\mathrm{HSO}_{4}{ }^{-}$, as in reaction $\mathrm{R}_{11}$ (see Scheme 1 ). ${ }^{86}$ We verified that relative $m / z^{-}=79,80,95$, and 97 signal intensities do not change 
appreciably or show any significant trend with DMSO concentration over the $0.05-1.0 \mathrm{mM}$ range (Figure S6).

Figure 3 shows negative-ion ES mass spectral signals obtained from aqueous DMSO microjets exposed to gaseous $\mathrm{O}_{3} / \mathrm{O}_{2} /$

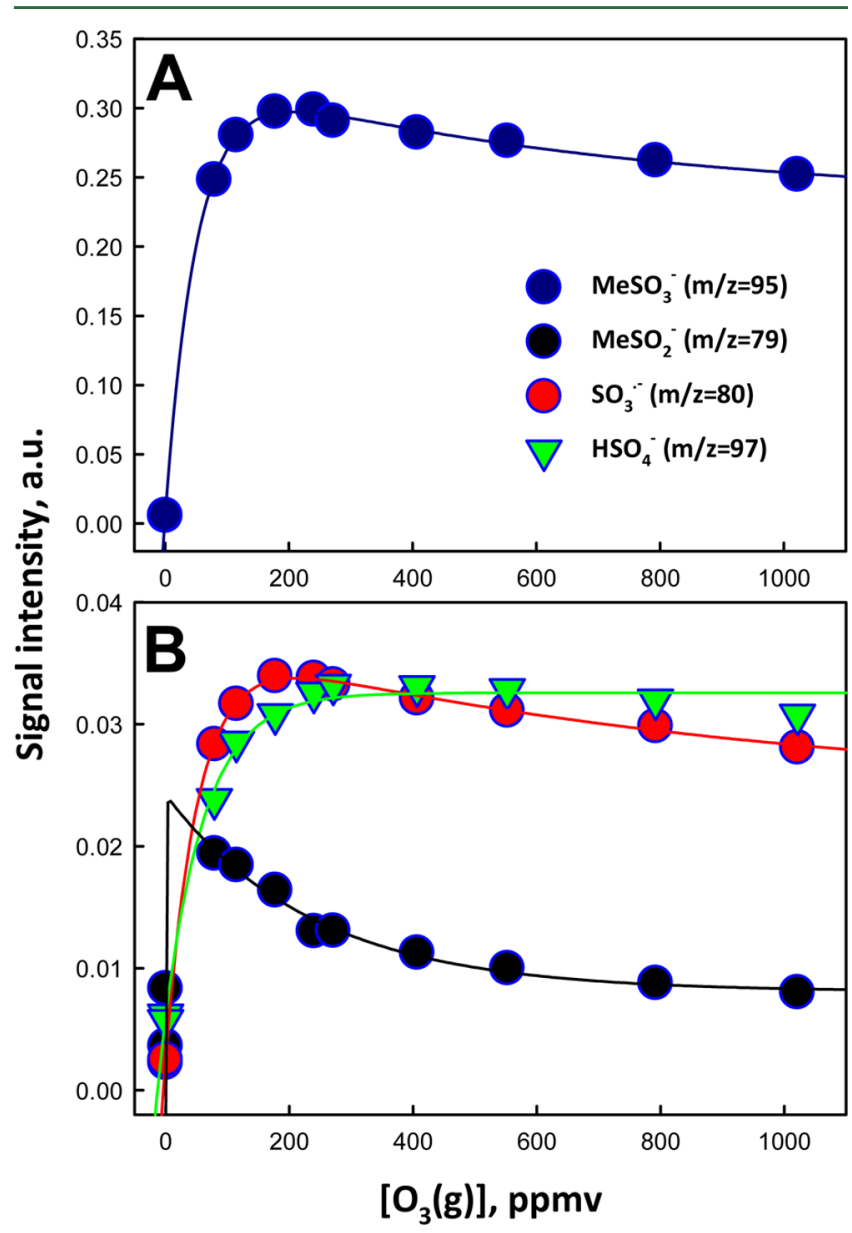

Figure 3. Mass spectral signal intensities of $\mathrm{MeSO}_{3}^{-}$(A), $\mathrm{MeSO}_{2}{ }^{-}$, $\mathrm{SO}_{3}{ }^{-}$, and $\mathrm{HSO}_{4}{ }^{-}$(B) from aqueous $1 \mathrm{mM} \mathrm{DMSO}$ microjets at $\mathrm{pH} \sim 7$ exposed to $\mathrm{O}_{3}(\mathrm{~g}) / \mathrm{O}_{2}(\mathrm{~g}) / \mathrm{H}_{2} \mathrm{O}(\mathrm{g}) / \mathrm{N}_{2}(\mathrm{~g})$ mixtures photolyzed with 266 $\mathrm{nm}$ laser pulses $\left(20 \mathrm{~mJ}\right.$ pulse $\left.\mathrm{s}^{-1}\right)$ as a function of $\mathrm{O}_{3}(\mathrm{~g})$ mixing ratio. $\left[\mathrm{O}_{3}(\mathrm{~g})\right](x$-axis) at 80 (the lowest value) and $1020 \mathrm{ppmv}$ (the highest value) corresponds to $[\cdot \mathrm{OH}(\mathrm{g})]_{0} \leq 4.4$ and $56.4 \mathrm{ppmv}$, respectively. Lines are regression curves fitted with double-exponential functions: $f=$ a $\left(1-\exp \left(-b\left[\mathrm{O}_{3}(\mathrm{~g})\right]\right)\right)+c\left(1-\exp \left(-d\left[\mathrm{O}_{3}(\mathrm{~g})\right]\right)\right)$, associated with assumed successive pseudo-first-order product formation and destruction processes.

$\mathrm{H}_{2} \mathrm{O} / \mathrm{N}_{2}$ mixtures under $266 \mathrm{~nm}$ irradiation as a function of $\left[\mathrm{O}_{3}(\mathrm{~g})\right]$, which reveal that $\mathrm{MeSO}_{3}{ }^{-}$is inert toward $\mathrm{O}_{3}$. Further experiments involving aqueous $\mathrm{MeSO}_{3}{ }^{-}$and $\mathrm{MeSO}_{2}{ }^{-}$solutions confirm that $\mathrm{MeSO}_{3}{ }^{-}$is also inert toward $\cdot \mathrm{OH}(\mathrm{g})$ (Figure S3). In marked contrast, $\mathrm{MeSO}_{2}{ }^{-}$reacts with both species, reactions $\mathrm{R}_{9}$ $\left(+\mathrm{R}_{10}\right)$ and $\mathrm{R}_{9^{\prime}}$, producing mainly $\mathrm{MeSO}_{3}{ }^{-}$plus some $\mathrm{HSO}_{4}{ }^{-}$ (Figures 3 and S7).

The ratio of raw mass spectral signal intensities $R_{\mathrm{SIG}}=\mathrm{I}_{95} / \mathrm{I}_{97}=$ $8.7 \pm 0.5$ in Figure $2 \mathrm{~B}$ (the experiment at the largest $\left[\mathrm{O}_{3}\right]$ and $[$. $\mathrm{OH}]$ ) was converted into the sought after $R_{\text {het }}=\left[\mathrm{MeSO}_{3}{ }^{-}\right] /$ $\left[\mathrm{SO}_{4}{ }^{2-}\right]$ ratio by using an experimental $\mathrm{I}_{95} / \mathrm{I}_{97}$ vs $\mathrm{pH}$ calibration curve obtained from the ES mass spectra of formulated equimolar $\mathrm{MeSO}_{3}{ }^{-}+\mathrm{HSO}_{4}{ }^{-}$solutions at various $\mathrm{pHs}$ (Figure S8). $\mathrm{pH}$ values correspond to the $\mathrm{pH}$ of the injected solutions in all cases, which were determined by means of a calibrated $\mathrm{pH}$ meter prior to injection. Figure $\mathrm{S} 8$ shows that $\mathrm{I}_{95} / \mathrm{I}_{97}$ is an increasing sigmoidal function of $\mathrm{pH}$, as expected from the fact that the concentration of the relatively weak acid $\mathrm{HSO}_{4}{ }^{-}$that gives rise to the $m / z=97$ signal decreases at higher $\mathrm{pH}$ as it becomes converted into $\mathrm{SO}_{4}{ }^{2-}\left(\mathrm{SO}_{4}{ }^{2-}\right.$ is a doubly charged ion that would not appear in the mass spectra). Under the conditions of the oxidation experiments of Figure $2 \mathrm{~B}$ (that is, at $\mathrm{pH} 7$ ), we get $\mathrm{I}_{95} / \mathrm{I}_{97}=3.2$ from Figure S8. In other words, an equimolar solution of $\mathrm{MeSO}_{3}{ }^{-}$and sulfate at $\mathrm{pH} 7$ gives rise to $\mathrm{m} / z=95$ signals that are 3.2 times larger than those of $\mathrm{HSO}_{4}{ }^{-}$at $m / z=97$. Therefore, the $R_{\mathrm{SIG}}=\mathrm{I}_{95} / \mathrm{I}_{97}=8.7$ ratio determined in our oxidation experiments was divided by 3.2 to account for the fact that only a fraction of total sulfate is present as $\mathrm{HSO}_{4}{ }^{-}$at $\mathrm{pH} 7$. On this basis we derived a $R_{\text {het }} \sim 2.7$ value, i.e., the oxidation of $\mathrm{DMSO}(\mathrm{aq})$ by $\cdot \mathrm{OH}(\mathrm{g})$ at the air-water interface actually produces 2.7 times more $\mathrm{MeSO}_{3}{ }^{-}$than sulfate.

The fact that $\mathrm{MeSO}_{3}{ }^{-}$is the product of four successive reactions $\left(\mathrm{R}_{7}\right.$ to $\left.\mathrm{R}_{10}\right)$ in which $\cdot \mathrm{OH}$ participates twice (reactions $\mathrm{R}_{7}$ and $\mathrm{R}_{9}$ ) within $50 \mu \mathrm{s}$, implies that $\mathrm{MeSO}_{2}{ }^{-}$is far more reactive than DMSO toward $\cdot \mathrm{OH}$. This finding furthermore implies that . $\mathrm{OH}$ radicals remain a finite time in the topmost interfacial layers before diffusing into the bulk liquid. Previous studies had indeed suggested that $\cdot \mathrm{OH}$ prefers the air-water interface over bulk water. ${ }^{51,52,63,87-89}$ The finding that $\mathrm{MeSO}_{3}{ }^{-}$is the major product of the oxidation process initiated by the reaction of $\mathrm{DMSO}(\mathrm{aq})$ with $\cdot \mathrm{OH}(\mathrm{g})\left(\mathrm{R}_{5}\right)$ at the air-water interface is in line with previously reported experiments in which $\mathrm{DMSO}(\mathrm{aq})$ was oxidized by $\cdot \mathrm{OH}(\mathrm{aq})$ generated from the photolysis of $\mathrm{H}_{2} \mathrm{O}_{2}(\mathrm{aq})$ or $\mathrm{NO}_{3}{ }^{-}$(aq) in bulk water. ${ }^{29,66}$ The similar behaviors in both media suggest that $\cdot \mathrm{OH}(\mathrm{g})$ becomes aquated as $\cdot \mathrm{OH}(\mathrm{aq})$ upon hitting the surface and then adds to a solvated DMSO S-atom. This scenario is supported by a surface-specific spectroscopic study showing that the hydrophobic DMSO methyl groups point to the air, as expected, whereas the target $S$-atom dips into water, where it is fully solvated. ${ }^{40}$

The nearly quantitative production of $\mathrm{SO}_{4}{ }^{2-}$ in the oxidation of DMSO in the gas phase versus the $R_{\text {het }} \sim 2.7$ value determined at the air-water interface means that $\mathrm{R}=\mathrm{MeSO}_{3}{ }^{-} / \mathrm{nss}^{-} \mathrm{SO}_{4}{ }^{2-}$ variations in the aerosol, particularly in pristine, remote locations where anthropogenic contributions to nss- $\mathrm{SO}_{4}{ }^{2-}$ are minimal, should arise from the competition between the gas phase versus the heterogeneous DMSO oxidation pathways. Below, this clearcut chemical criterion is applied to interpret new results on the $\mathrm{MeSO}_{3}{ }^{-}$and nss- $\mathrm{SO}_{4}{ }^{2-}$ composition of size-segregated aerosol collected in the boundary marine layer over wide latitudinal spans in the Southern oceans. To our knowledge, this is the first time a full, quantitative understanding of the chemistry involved in these transformations is applied to analyze $\mathrm{R}=\mathrm{MeSO}_{3}^{-} / \mathrm{nss}$ $\mathrm{SO}_{4}{ }^{2-}$ field measurements.

Composition of Size-Segregated Aerosols. Figure 4 shows data for aerosol collected over Syowa in austral summers, defined herein as the periods between November 1 and February 28 and in austral winters, which cover the rest of the years. Measurements extended from February 19, 2004 to December 6, 2006.

It is apparent that in both seasons, $R$ for $<0.2 \mu \mathrm{m}$ aerosols is larger and increases more steeply with aerosol mass than for the $0.2-2 \mu \mathrm{m}$ fraction. We found that $\left[\mathrm{MeSO}_{3}{ }^{-}\right]$increases approximately as a quadratic function of $\left[\mathrm{nss}^{-\mathrm{SO}_{4}}{ }^{2-}\right]$ in both cases. Considering that $\mathrm{MeSO}_{3}{ }^{-}$is only produced heterogeneously, the finding that the quadratic (see explanation in captions to Figures 4 and 5) $\mathrm{MeSO}_{3}{ }^{-}$versus nss- $\mathrm{SO}_{4}{ }^{2-}$ dependences become steeper in the finer fraction clearly points 

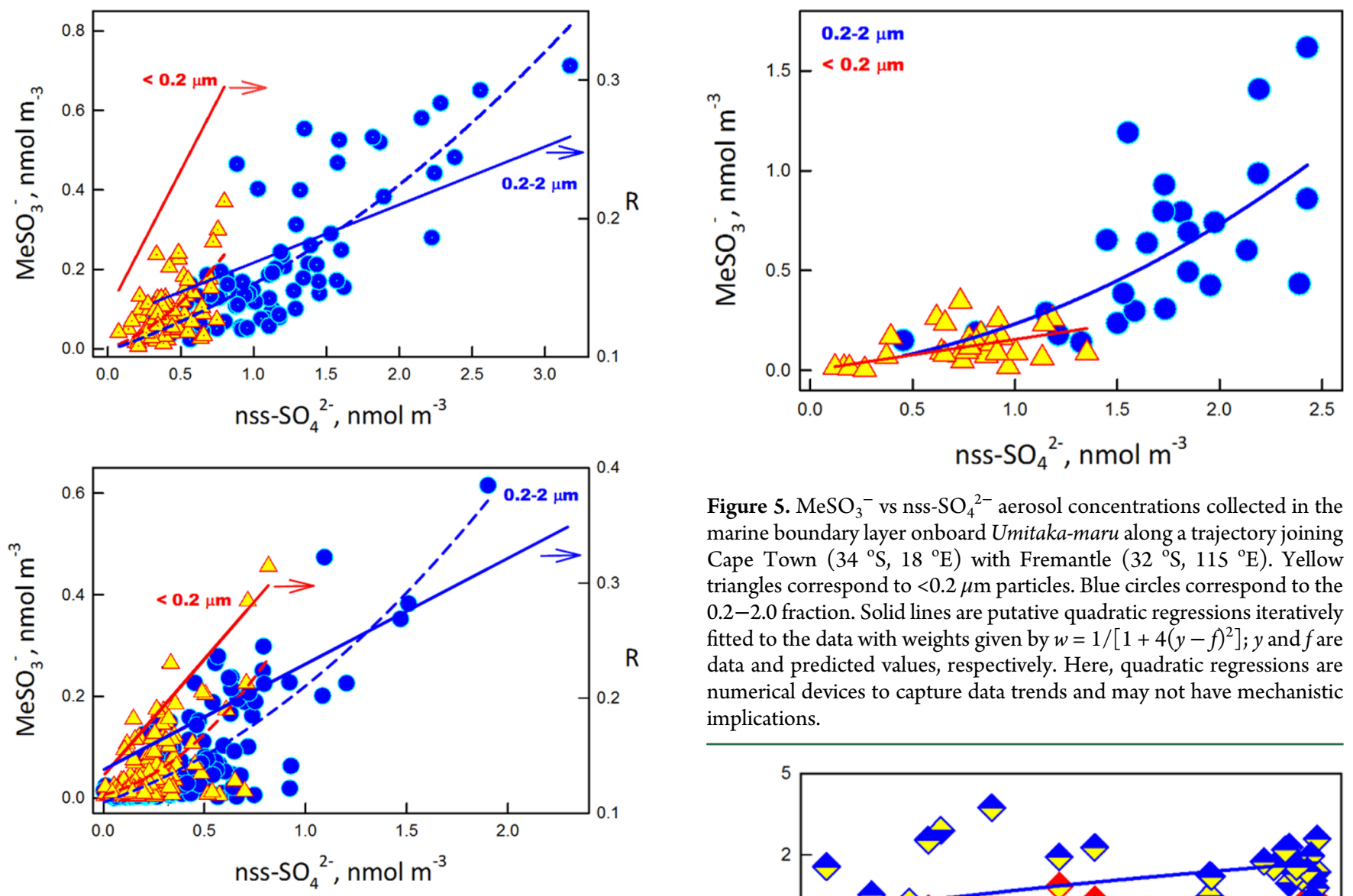

Figure 5. $\mathrm{MeSO}_{3}{ }^{-}$vs nss- $\mathrm{SO}_{4}{ }^{2-}$ aerosol concentrations collected in the marine boundary layer onboard Umitaka-maru along a trajectory joining Cape Town $\left(34^{\circ} \mathrm{S}, 18^{\circ} \mathrm{E}\right)$ with Fremantle $\left(32^{\circ} \mathrm{S}, 115^{\circ} \mathrm{E}\right)$. Yellow triangles correspond to $<0.2 \mu \mathrm{m}$ particles. Blue circles correspond to the $0.2-2.0$ fraction. Solid lines are putative quadratic regressions iteratively fitted to the data with weights given by $w=1 /\left[1+4(y-f)^{2}\right] ; y$ and $f$ are data and predicted values, respectively. Here, quadratic regressions are numerical devices to capture data trends and may not have mechanistic implications.

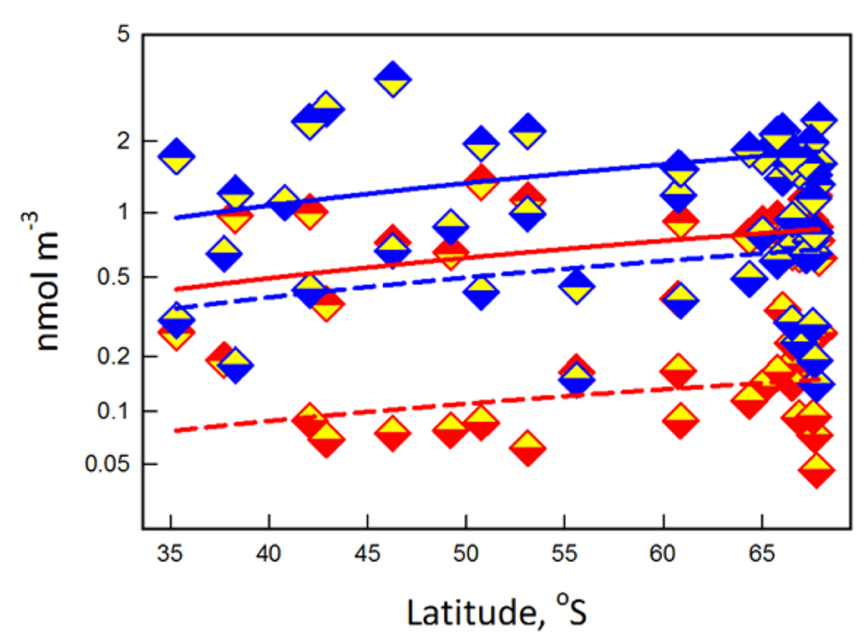

to an increasing contribution of DMSO interfacial oxidation to the composition of denser aerosols. Our findings are in contrast with previous observations at Point Reyes (California), which found that MSA is mainly present in relatively large sea salt particles rather than in secondary $\left(\mathrm{NH}_{4}\right)_{2} \mathrm{SO}_{4}$ aerosol particles. ${ }^{35}$ The California study, however, pointed out that "the observed selectivity of $\mathrm{CH}_{3} \mathrm{SO}_{3}{ }^{-}$to sea salt particles is quite puzzling and additional studies are required to understand this discrepancy (with comprehensive model calculations) ${ }^{35}$ ".

Figure 5 shows similar data, this time collected by Umitakamaru between Cape Town and Freemantle during 2005 and 2006.

Figure 6 displays the data of Figure 5 as a function of latitude, which is complemented with the contour plots of $R$ as functions of latitude and nss- $\mathrm{SO}_{4}{ }^{2-}$ concentration of Figures 7 and S9.

The general (putative) quadratic dependence of $\left[\mathrm{MeSO}_{3}{ }^{-}\right]$on $\left[\right.$ nss- $\left.\mathrm{SO}_{4}{ }^{2-}\right]$ is also manifested in the Umitaka-maru data, although in this case it should be kept in mind that data $<0.2$ $\mu \mathrm{m}$ and $0.2-2 \mu \mathrm{m}$ data may not correspond to same locations. Note that the ratio $R$ peaks at high latitudes for both fractions in spite of their dissimilar concentrations (Figures 6 and 7). We

Figure 6. $\mathrm{MeSO}_{3}{ }^{-}$and nss- $\mathrm{SO}_{4}{ }^{2-}$ aerosol concentrations as functions of latitude. Aerosol collected onboard Umitaka-maru in the marine boundary layer along a trajectory joining Cape Town $\left(34^{\circ} \mathrm{S}, 18{ }^{\circ} \mathrm{E}\right)$ with Fremantle $\left(32^{\circ} \mathrm{S}, 115^{\circ} \mathrm{E}\right)$. Yellow-red diamonds are $\mathrm{MeSO}_{3}{ }^{-}$data; yellow-blue diamonds are nss- $\mathrm{SO}_{4}{ }^{2-}$ data. Upper yellow data correspond to $<0.2 \mu \mathrm{m}$ particles; lower yellow data correspond to the $0.2-2.0$ fraction.

wish to emphasize that our key finding is not the large $R$ values per se (large $R>0.6$ values have been reported before) ${ }^{35}$ but the analysis of the inverse dependence of $R$ on particle radius on the basis of the causative chemistry firmly established by our experiments. In other words, only by knowing (rather than by assuming an arbitrary value) that $R_{\text {het }} \sim 2.7$, and by incorporating the most recent results on the gas-phase oxidation chemistry of both DMS and DMSO, a physically meaningful analysis of the inverse dependence of $R$ on particle radius could be made (see below).

The above results can be interpreted in terms of the competition between $\mathrm{DMSO}(\mathrm{g})$ gas-phase oxidation and its mass accommodation on the surface of aqueous droplets. From 

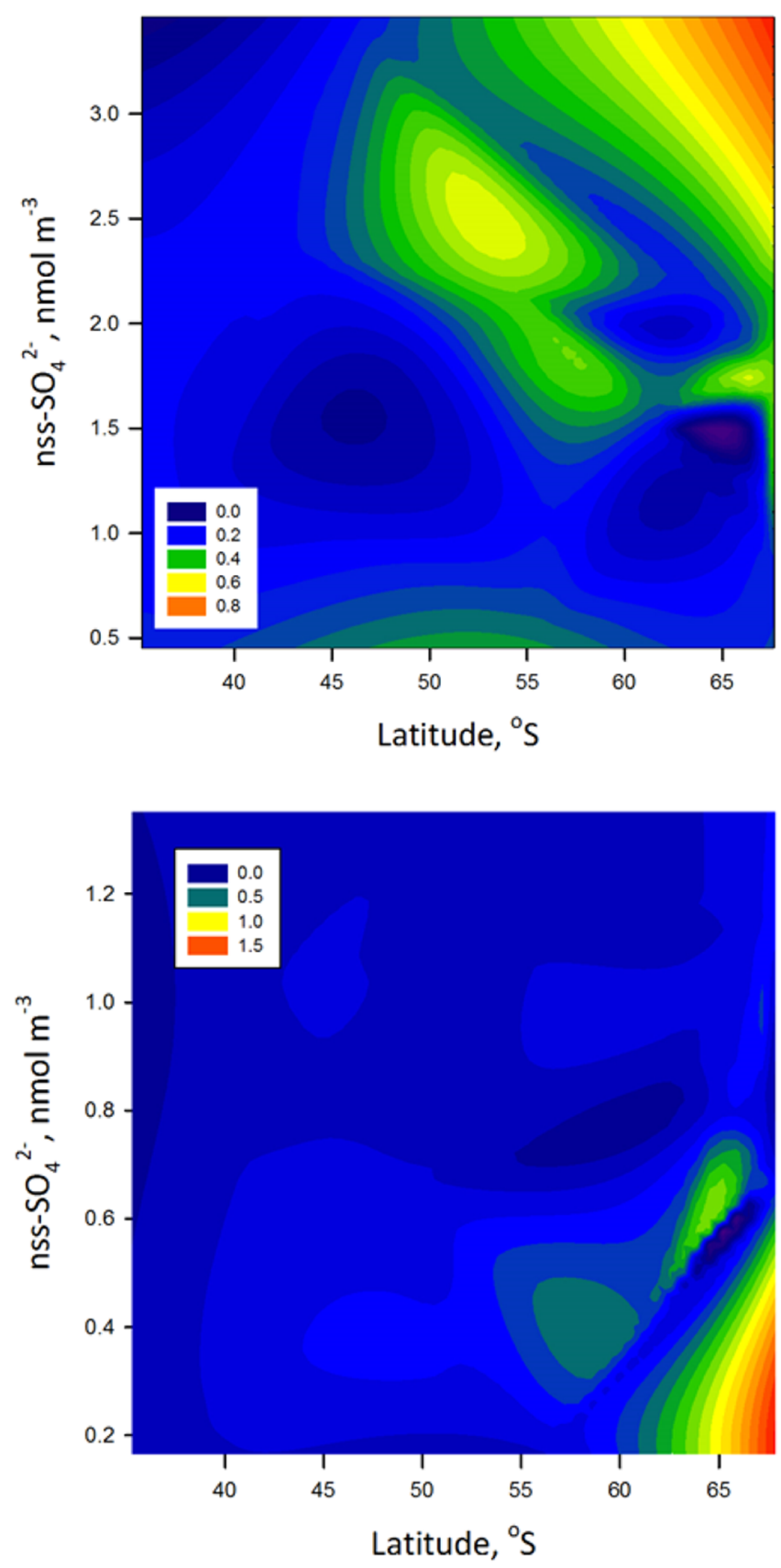

Figure 7. Contour plots of $\mathrm{R}=\mathrm{MeSO}_{3}{ }^{-} / \mathrm{nss}-\mathrm{SO}_{4}{ }^{2-}$ as a function of latitude and nss- $\mathrm{SO}_{4}{ }^{2-}$ concentration in aerosols collected in the marine boundary layer onboard Umitaka-maru along a trajectory joining Cape Town $\left(34^{\circ} \mathrm{S}, 18^{\circ} \mathrm{E}\right)$ with Fremantle $\left(32^{\circ} \mathrm{S}, 115^{\circ} \mathrm{E}\right)$. The upper panel corresponds to $0.2-2.0 \mu \mathrm{m}$ particles. The lower panel is for the $<0.2 \mu \mathrm{m}$ fraction. The largest $R$ values occur at high latitudes in both cases.

the reported value of the mass accommodation coefficient of DMSO on water (i.e., the probability that a DMSO gas molecule enters the liquid upon striking the liquid surface): $\alpha=0.1,{ }^{24}$ we calculate the frequency $f_{\alpha}$ at which DMSO gas molecules are sequestered from the gas phase by using eq E1 given by the kinetic theory of gases: ${ }^{90}$

$$
f_{\alpha}\left(s^{-1}\right)=\left(\frac{1}{4}\right) \alpha c\left(\frac{S}{V}\right)
$$

where $c=3.3 \times 10^{4} \mathrm{~cm} \mathrm{~s}^{-1}$ is the average thermal velocity of DMSO molecules at ambient temperatures, and $(S / V)$ is the specific surface area of the aerosol ensemble per unit volume of air. Thus: $f_{\alpha}=8.3 \times 10^{2} \cdot(\mathrm{S} / \mathrm{V}) \mathrm{s}^{-1} \sim 10^{3} \cdot(\mathrm{S} / \mathrm{V}) \mathrm{s}^{-1}$ under typical conditions. Note that the diffusional resistance to the approach of gas molecules to particles is negligible for $<2 \mu \mathrm{m}$ particles in air at $1 \mathrm{~atm} .^{24}$ The frequency of the competing process, namely the frequency at which $\mathrm{DMSO}(\mathrm{g})$ will react with $\cdot \mathrm{OH}(\mathrm{g})$ in the gas phase at typical $[\cdot \mathrm{OH}(\mathrm{g})]=1 \times 10^{6}$ molecules $\mathrm{cm}^{-3}, 91,92$ is $f_{\mathrm{OH}}=$ $k_{\mathrm{DMSO}+\mathrm{OH}} \times[\cdot \mathrm{OH}(\mathrm{g})] \sim 1 \times 10^{-4} \mathrm{~s}^{-1}$, with $k_{\mathrm{DMSO}+\mathrm{OH}}=9 \times$ $10^{-11}\left(\mathrm{~cm}^{3}\right.$ molecule $\left.^{-1} \mathrm{~s}^{-1}\right){ }^{26}$ The $\Gamma=f_{\alpha} / f_{\mathrm{OH}} \sim 1 \times 10^{7}(\mathrm{~S} / \mathrm{V})$ ratio quantifies the competition between the heterogeneous and homogeneous DMSO oxidation pathways.

$(S / V)$ values can be estimated from the surface area A of individual spherical particles of radius $\rho$ and their number density $\Omega(\rho): \mathrm{S} / \mathrm{V}=\mathrm{A}(\rho) \Omega(\rho)$. Thus, for $\rho=0.3-0.5 \mu \mathrm{m}$ particles with $\mathrm{A}=4 \pi \rho^{2}=2 \times 10^{-8} \mathrm{~cm}^{2}$, and typical $\Omega \sim 1$ particle $\mathrm{cm}^{-3}$ values at ground level in Syowa, ${ }^{93}$ we get: $(\mathrm{S} / \mathrm{V})=\mathrm{A} \times \Omega \sim 2 \times 10^{-8}$ $\mathrm{cm}^{-1}$. Therefore, $\Gamma \sim 0.2$ for $\rho=0.3-0.5 \mu \mathrm{m}$. This order-ofmagnitude estimates show that the heterogeneous oxidation of DMSO leading to $\mathrm{MeSO}_{3}{ }^{-}$and nss- $\mathrm{SO}_{4}{ }^{2-}$ in a 2.7:1 ratio on the surface of aerosol particles can compete with its gas-phase oxidation into $\mathrm{H}_{2} \mathrm{SO}_{4}(\mathrm{~g})$ under representative atmospheric conditions. Naturally, actual $\Gamma=f_{\alpha} / f_{\mathrm{OH}}$ ratios might depend on other factors, such as the overall composition of the aerosol. For example, one could expect departures from the above simplified scheme on coarse aerosol grown on primary marine aerosol carrying seawater organic matter. It should be emphasized that the large $H_{\text {DMSO,WATER }} \approx 10^{7} \mathrm{M} \mathrm{atm}^{-1}$ value ensures that $\mathrm{DMSO}(\mathrm{g})$ molecules are in effect irreversibly scavenged upon collision with aqueous aerosol droplets, where they remain until they are oxidized into $\mathrm{MeSO}_{3}{ }^{-}$and $\mathrm{SO}_{4}{ }^{2-}$ in a 2.7:1 ratio.

By assuming that anthropogenic $\mathrm{SO}_{4}{ }^{2-}$ makes negligible contributions to nss- $\mathrm{SO}_{4}{ }^{2-}$, which is a valid assumption in the clean, high-latitude Southern atmospheres, and that the oxidation of DMS produces $50 \% \mathrm{H}_{2} \mathrm{SO}_{4}(\mathrm{~g})+50 \% \mathrm{DMSO}(\mathrm{g})$, it can be shown that $R$ is a modified Pareto function of $\Gamma: R=1-$ $(1+2.2 \Gamma)^{-0.23}$ (see $R$ versus $\Gamma$ in the appendix in the Supporting Information). For example, a $R=0.1$ value arises from the competition between heterogeneous-to-homogeneous oxidation pathways in a $\Gamma \sim 0.3$ ratio.

It is apparent that the production of aerosol-phase $\mathrm{MeSO}_{3}{ }^{-}$is in effect an autocatalytic process whose rate increases with $\Omega .{ }^{94}$ Heterogeneous DMSO oxidation will be particularly important at higher latitudes over ocean regions sustaining intense photosynthetic activity, i.e., where strong DMS emissions will enhance the production of CCN. This statement follows from considering that if all DMS terminates as $\mathrm{CCN}$, i.e., the mass of gaseous DMS per unit volume of air, $M$, is quantitatively converted into particles of average radius $\rho$, then: $M=\Omega(4 / 3) \pi$ $\rho^{3} \delta,\left(\delta \sim 1.5 \mathrm{~g} \mathrm{~cm}^{-3}\right.$ is a typical CCN mass density $)$, i.e., $\Omega=$ $3 \mathrm{M} /\left(4 \pi \rho^{3} \delta\right)$. Hence, $\mathrm{S} / \mathrm{V}$ is directly proportional to $\mathrm{M}$ (which is proportional to the strength of DMS emissions) and inversely proportional to particle radius $\rho: \mathrm{S} / \mathrm{V}=\Omega \times \mathrm{A}=3 \mathrm{M} /\left(4 \pi \rho^{3} \delta\right) \times$ $4 \pi \rho^{2}=3 \mathrm{M} /(\rho \delta)$. It is apparent that the high $(\mathrm{S} / \mathrm{V})$ ratio of the ultrafine CCN generated from strong DMS emissions will favor a heterogeneous process that adds mass to the aerosol in a $R_{\text {het }} \sim$ $2.7=\mathrm{MeSO}_{3}{ }^{-} / \mathrm{nss}^{-} \mathrm{SO}_{4}{ }^{2-}$ ratio.

In conclusion, we report new laboratory experiments on the atmospherically relevant oxidation of dimethyl sulfoxide (DMSO) by $\cdot \mathrm{OH}(\mathrm{g})$ radicals at the air-water interfaces, and field data on methane-sulfonate $\left(\mathrm{MeSO}_{3}{ }^{-}\right)$and $\mathrm{nss}^{-\mathrm{SO}_{4}}{ }^{-}$ concentrations in size-segregated aerosol particles collected in the marine boundary layer, which quantify the role of 
heterogeneous processes in determining the fraction of dimethyl sulfide biogenic emissions converted into methane-sulfonate. Our laboratory experiments, by establishing the mechanism of the $\cdot \mathrm{OH}$-initiated oxidation of DMSO into $\mathrm{MeSO}_{3}{ }^{-}$and $\mathrm{SO}_{4}{ }^{2-}$ in a $R_{\text {het }}=\mathrm{MeSO}_{3}{ }^{-} / \mathrm{SO}_{4}{ }^{2-} \sim 2.7$ ratio at the air-water interface, let us extract the significance of the size-segregated aerosol field data $R=\mathrm{MeSO}_{3}{ }^{-} /$nss-SO ${ }_{4}{ }^{2-}$ collected at the Syowa Station in Antarctica and over wide reaches of the Southern Ocean. Our analysis accounts for the positive $\mathrm{R}=\mathrm{MeSO}_{3}{ }^{-} / \mathrm{nss}-\mathrm{SO}_{4}{ }^{2-}$ versus nss- $\mathrm{SO}_{4}{ }^{2-}$ correlations under all conditions, which are stronger in $<0.2 \mu \mathrm{m}$ particles than in the $0.2-2.0 \mu \mathrm{m}$ fraction and systematically increase at higher latitudes, and reveals that interfacial oxidation processes play a more significant role in the generation and growth of atmospheric aerosol than previously envisioned.

\section{ASSOCIATED CONTENT}

\section{S Supporting Information}

The Supporting Information is available free of charge on the ACS Publications website at DOI: 10.1021/acs.est.5b05337.

Additional details on methods, $R$ vs $\Gamma$, and Figures S1-S9 (PDF)

\section{AUTHOR INFORMATION}

\section{Corresponding Authors}

*Phone: +81-774-38-4601; fax: +81-774-31-8463; e-mail: enami. shinichi.3r@kyoto-u.ac.jp.

*Phone: +1-626-395-6350; e-mail: ajcoluss@caltech.edu.

\section{Notes}

The authors declare no competing financial interest.

\section{ACKNOWLEDGMENTS}

S.E. is grateful to the Iwatani Naoji Foundation's Research Grant, the Kurita Water and Environment Foundation, the Japan Science and Technology Agency (JST) PRESTO program, and JSPS KAKENHI grant number 15H05328. M.R.H. and A.J.C. acknowledge support from the National Science Foundation (U.S.A.) Grant AC-1238977. Aerosol measurements at Syowa Station, Antarctica were supported by "Observation Project of Global Atmospheric Change in the Antarctic" (Principal Investigator: T. Yamanouchi, NIPR), and Grant-in-Aid (16253001, Principal Investigator: T. Yamanouchi, and 15310012, Principle Investigator: K. Osada) from the Ministry of Education, Culture, Sports, Science, and Technology of Japan. Aerosol measurements on RV Umitaka-maru were supported by a Grant-in-Aid for Scientific Research in Priority Areas, grant number 18067005 (W-PASS), provided by the Ministry of Education, Culture, Sports, Science, and Technology of Japan.

\section{REFERENCES}

(1) Almeida, J.; Schobesberger, S.; Kurten, A.; Ortega, I. K.; KupiainenMaatta, O.; Praplan, A. P.; Adamov, A.; Amorim, A.; Bianchi, F.; Breitenlechner, M.; et al. Molecular understanding of sulphuric acidamine particle nucleation in the atmosphere. Nature 2013, 502, 359363.

(2) Riccobono, F.; Schobesberger, S.; Scott, C. E.; Dommen, J.; Ortega, I. K.; Rondo, L.; Almeida, J.; Amorim, A.; Bianchi, F.; Breitenlechner, M.; et al. Oxidation Products of Biogenic Emissions Contribute to Nucleation of Atmospheric Particles. Science 2014, 344, 717-721.

(3) Kettle, A. J.; Andreae, M. O.; Amouroux, D.; Andreae, T. W.; Bates, T. S.; Berresheim, H.; Bingemer, H.; Boniforti, R.; Curran, M. A. J.; DiTullio, G. R.; et al. A global database of sea surface dimethylsulfide (DMS) measurements and a procedure to predict sea surface DMS as a function of latitude, longitude, and month. Global Biogeochem. Cycles 1999, 13, 399-444.

(4) Carslaw, K. S.; Lee, L. A.; Reddington, C. L.; Mann, G. W.; Pringle, $\mathrm{K}$. J. The magnitude and sources of uncertainty in global aerosol. Faraday Discuss. 2013, 165, 495-512.

(5) Carslaw, K. S.; Lee, L. A.; Reddington, C. L.; Pringle, K. J.; Rap, A.; Forster, P. M.; Mann, G. W.; Spracklen, D. V.; Woodhouse, M. T.; Regayre, L. A.; et al. Large contribution of natural aerosols to uncertainty in indirect forcing. Nature 2013, 503, 67-71.

(6) Charlson, R. J.; Lovelock, J. E.; Andreae, M. O.; Warren, S. G. Oceanic phytoplankton, atmospheric sulfur, cloud albedo and climate. Nature 1987, 326, 655-661.

(7) Wilcox, L. J.; Highwood, E. J.; Booth, B. B. B.; Carslaw, K. S. Quantifying sources of inter-model diversity in the cloud albedo effect. Geophys. Res. Lett. 2015, 42, 1568-1575.

(8) Lucas, D. D.; Prinn, R. G. Sensitivities of gas-phase dimethylsulfide oxidation products to the assumed mechanisms in a chemical transport model. J. Geophys. Res. 2005, 110, 10.1029/2004JD005386.

(9) Gondwe, M.; Krol, M.; Gieskes, W.; Klaassen, W.; de Baar, H. The contribution of ocean-leaving DMS to the global atmospheric burdens of DMS, MSA, $\mathrm{SO}_{2}$, and nss-SO ${ }_{4}{ }^{\circ}$. Global Biogeochem. Cycles 2003, 17, 10.1029/2002GB001937.

(10) Gondwe, M.; Krol, M.; Klaassen, W.; Gieskes, W.; de Baar, H. Comparison of modeled versus measured MSA: nss- $\mathrm{SO}_{4}{ }^{=}$ratios: A global analysis. Global Biogeochem. Cycles 2004, 18,10.1029/ 2003 GB002144.

(11) Johansen, A. M.; Hoffmann, M. R. Chemical characterization of ambient aerosol collected during the northeast monsoon season over the Arabian Sea: Anions and cations. J. Geophys. Res. 2004, 109, D05305.

(12) Johansen, A. M.; Siefert, R. L.; Hoffmann, M. R. Chemical composition of aerosols collected over the tropical North Atlantic Ocean. J. Geophys. Res. 2000, 105, 15277-15312.

(13) Kanakidou, M.; Seinfeld, J. H.; Pandis, S. N.; Barnes, I.; Dentener, F. J.; Facchini, M. C.; Van Dingenen, R.; Ervens, B.; Nenes, A.; Nielsen, C. J.; et al. Organic aerosol and global climate modelling: a review. Atmos. Chem. Phys. 2005, 5, 1053-1123.

(14) Kerminen, V. M.; Hillamo, R. E.; Wexler, A. S. Model simulations on the variability of particulate MSA to non-sea-salt sulfate ratio in the marine environment. J. Atmos. Chem. 1998, 30, 345-370.

(15) Korhonen, H.; Carslaw, K. S.; Spracklen, D. V.; Mann, G. W.; Woodhouse, M. T. Influence of oceanic dimethyl sulfide emissions on cloud condensation nuclei concentrations and seasonality over the remote Southern Hemisphere oceans: A global model study. J. Geophys. Res. 2008, 113, 10.1029/2007JD009718.

(16) Langner, J.; Rodhe, H. A global 3-dimensional model of the tropospheric sulfur cycle. J. Atmos. Chem. 1991, 13, 225-263.

(17) Lehrer, E.; Honninger, G.; Platt, U. A one dimensional model study of the mechanism of halogen liberation and vertical transport in the polar troposphere. Atmos. Chem. Phys. 2004, 4, 2427-2440.

(18) Lewis, E. R.; Schwartz, S. E. Sea Salt Aerosol Production: Mechanisms, Methods, Measurements and Models - A Critical Review; American Geophysical Union: Washington, DC, 2004; Vol. Geophysical Monograph 152.

(19) van den Berg, A.; Dentener, F.; Lelieveld, S. Modeling the chemistry of the marine boundary layer: Sulphate formation and the role of sea-salt aerosol particles. J. Geophys. Res. 2000, 105, 11671-11698.

(20) von Glasow, R.; Crutzen, P. J. Model study of multiphase DMS oxidation with a focus on halogens. Atmos. Chem. Phys. 2004, 4, 589608.

(21) Finlayson-Pitts, B. J.; Pitts, J. N. Chemistry of the upper and lower atmosphere; Academic Press: San Diego, CA, 2000.

(22) Barnes, I.; Hjorth, J.; Mihalopoulos, N. Dimethyl sulfide and dimethyl sulfoxide and their oxidation in the atmosphere. Chem. Rev. 2006, 106, 940-975.

(23) Seinfeld, J. H.; Pandis, S. N. Atmospheric chemistry and physics: from air pollution to climate change; 2nd ed.; Wiley: Hoboken, N.J., 2006.

(24) Debruyn, W. J.; Shorter, J. A.; Davidovits, P.; Worsnop, D. R.; Zahniser, M. S.; Kolb, C. E. Uptake of gas-phase sulfur species 
methanesulfonic-acid, dimethylsulfoxide, and dimethyl sulfone by aqueous surfaces. J. Geophys. Res. 1994, 99, 16927-16932.

(25) Sander, R. Compilation of Henry's law constants (version 4.0) for water as solvent. Atmos. Chem. Phys. 2015, 15, 4399-4981.

(26) Kukui, A.; Borissenko, D.; Laverdet, G.; Le Bras, G. Gas-phase reactions of $\mathrm{OH}$ radicals with dimethyl sulfoxide and methane sulfinic acid using turbulent flow reactor and chemical ionization mass spectrometry. J. Phys. Chem. A 2003, 107, 5732-5742.

(27) Ammann, M.; Cox, R. A.; Crowley, J. N.; Jenkin, M. E.; Mellouki, A.; Rossi, M. J.; Troe, J.; Wallington, T. J. Evaluated kinetic and photochemical data for atmospheric chemistry: Volume VI heterogeneous reactions with liquid substrates. Atmos. Chem. Phys. 2013, 13, 8045-8228.

(28) Zhu, L.; Nenes, A.; Wine, P. H.; Nicovich, J. M. Effects of aqueous organosulfur chemistry on particulate methanesulfonate to non-sea salt sulfate ratios in the marine atmosphere. J. Geophys. Res. 2006, 111, $10.1029 / 2005 J D 006326$.

(29) Zhu, L.; Nicovich, J. M.; Wine, P. H. Temperature-dependent kinetics studies of aqueous phase reactions of hydroxyl radicals with dimethylsulfoxide, dimethylsulfone, and methanesulfonate. Aquat. Sci. 2003, 65, 425-435.

(30) Chen, L. Q.; Wang, J. J.; Gao, Y.; Xu, G. J.; Yang, X. L.; Lin, Q.; Zhang, Y. H. Latitudinal distributions of atmospheric MSA and MSA/ nss- $\mathrm{SO}_{4}{ }^{2-}$ ratios in summer over the high latitude regions of the Southern and Northern Hemispheres. J. Geophys. Res. 2012, 117, 10.1029/ 2011JD016559.

(31) Arsene, C.; Barnes, I.; Becker, K. H.; Schneider, W. F.; Wallington, T. T.; Mihalopoulos, N.; Patroescu-Klotz, I. V. Formation of methane sulfinic acid in the gas-phase OH-radical initiated oxidation of dimethyl sulfoxide. Environ. Sci. Technol. 2002, 36, 5155-5163.

(32) Turnipseed, A. A.; Barone, S. B.; Ravishankara, A. R. Reaction of $\mathrm{OH}$ with dimethyl sulfide. 2. Products and mechanisms. J. Phys. Chem. 1996, 100, 14703-14713.

(33) Davis, D.; Chen, G.; Kasibhatla, P.; Jefferson, A.; Tanner, D.; Eisele, F.; Lenschow, D.; Neff, W.; Berresheim, H. DMS oxidation in the Antarctic marine boundary layer: Comparison of model simulations and field observations of DMS, DMSO, $\mathrm{DMSO}_{2}, \mathrm{H}_{2} \mathrm{SO}_{4}(\mathrm{~g}), \mathrm{MSA}(\mathrm{g})$, and MSA(p). J. Geophys. Res. 1998, 103, 1657-1678.

(34) Allen, A. G.; Dick, A. L.; Davison, B. M. Sources of atmospheric methanesulphonate, non-sea-salt sulphate, nitrate and related species over the temperate South Pacific. Atmos. Environ. 1997, 31, 191-205.

(35) Hopkins, R. J.; Desyaterik, Y.; Tivanski, A. V.; Zaveri, R. A.; Berkowitz, C. M.; Tyliszczak, T.; Gilles, M. K.; Laskin, A. Chemical speciation of sulfur in marine cloud droplets and particles: Analysis of individual particles from the marine boundary layer over the California current. J. Geophys. Res. 2008, 113, 10.1029/2007JD008954.

(36) Bardouki, H.; Berresheim, H.; Vrekoussis, M.; Sciare, J.; Kouvarakis, G.; Oikonomou, K.; Schneider, J.; Mihalopoulos, N. Gaseous (DMS, MSA, $\mathrm{SO}_{2}, \mathrm{H}_{2} \mathrm{SO}_{4}$ and DMSO) and particulate (sulfate and methanesulfonate) sulfur species over the northeastern coast of Crete. Atmos. Chem. Phys. 2003, 3, 1871-1886.

(37) Cox, R. A.; Sheppard, D. Reactions of OH radicals with gaseous sulfur-compounds. Nature 1980, 284, 330-331.

(38) Buxton, G. V.; Greenstock, C. L.; Helman, W. P.; Ross, A. B. Critical review of rate constants for reactions of hydrated electrons, hydrogen-atoms and hydroxyl radicals $\left(\cdot \mathrm{OH} / \cdot \mathrm{O}^{-}\right)$in aqueous-solution. J. Phys. Chem. Ref. Data 1988, 17, 513-886.

(39) Allen, H. C.; Gragson, D. E.; Richmond, G. L. Molecular structure and adsorption of dimethyl sulfoxide at the surface of aqueous solutions. J. Phys. Chem. B 1999, 103, 660-666.

(40) Tarbuck, T. L.; Richmond, G. L. Adsorption of organosulfur species at aqueous surfaces: Molecular bonding and orientation. J. Phys. Chem. B 2005, 109, 20868-20877.

(41) Chen, X. K.; Minofar, B.; Jungwirth, P.; Allen, H. C. Interfacial Molecular Organization at Aqueous Solution Surfaces of Atmospherically Relevant Dimethyl Sulfoxide and Methanesulfonic Acid Using Sum Frequency Spectroscopy and Molecular Dynamics Simulation. J. Phys. Chem. B 2010, 114, 15546-15553.
(42) Darvas, M.; Pojjak, K.; Horvai, G.; Jedlovszky, P. Molecular dynamics simulation and identification of the truly interfacial molecules (ITIM) analysis of the liquid-vapor interface of dimethyl sulfoxide. J. Chem. Phys. 2010, 132, 13470110.1063/1.3368111.

(43) Dabkowski, J.; Zagorska, I.; Dabkowska, M.; Koczorowski, Z.; Trasatti, S. Adsorption of DMSO at the free surface of water: Surface excesses and surface potential shifts in the low concentration range. J. Chem. Soc., Faraday Trans. 1996, 92, 3873-3878.

(44) Karpovich, D. S.; Ray, D. Adsorption of dimethyl sulfoxide to the liquid/vapor interface of water and the thermochemistry of transport across the interface. J. Phys. Chem. B 1998, 102, 649-652.

(45) Enami, S.; Hoffmann, M. R.; Colussi, A. J. Acidity enhances the formation of a persistent ozonide at aqueous ascorbate/ozone gas interfaces. Proc. Natl. Acad. Sci. U. S. A. 2008, 105, 7365-7369.

(46) Enami, S.; Hoffmann, M. R.; Colussi, A. J. Prompt formation of organic acids in pulse ozonation of terpenes on aqueous surfaces. J. Phys. Chem. Lett. 2010, 1, 2374-2379.

(47) Enami, S.; Hoffmann, M. R.; Colussi, A. J. Dry Deposition of Biogenic Terpenes via Cationic Oligomerization on Environmental Aqueous Surfaces. J. Phys. Chem. Lett. 2012, 3, 3102-3108.

(48) Enami, S.; Mishra, H.; Hoffmann, M. R.; Colussi, A. J. Protonation and oligomerization of gaseous isoprene on mildly acidic surfaces: Implications for Atmospheric Chemistry. J. Phys. Chem. A 2012, 116, 6027-6032.

(49) Enami, S.; Sakamoto, Y.; Colussi, A. J. Fenton chemistry at aqueous interfaces. Proc. Natl. Acad. Sci. U. S. A. 2014, 111, 623-628.

(50) Baptista, L.; da Silva, E. C.; Arbilla, G. Oxidation mechanism of dimethyl sulfoxide (DMSO) by OH radical in liquid phase. Phys. Chem. Chem. Phys. 2008, 10, 6867-6879.

(51) Enami, S.; Hoffmann, M. R.; Colussi, A. J. In Situ Mass Spectrometric Detection of Interfacial Intermediates in the Oxidation of $\mathrm{RCOOH}(\mathrm{aq})$ by Gas-Phase OH-Radicals. J. Phys. Chem. A 2014, 118, $4130-4137$.

(52) Enami, S.; Hoffmann, M. R.; Colussi, A. J. Stepwise Oxidation of Aqueous Dicarboxylic Acids by Gas-Phase OH Radicals. J. Phys. Chem. Lett. 2015, 6, 527-534.

(53) Enami, S.; Colussi, A. J. Long-range specific ion-ion interactions in hydrogen-bonded liquid films. J. Chem. Phys. 2013, 138, 184706.

(54) Enami, S.; Colussi, A. J. Ion-Specific Long-Range Correlations on Interfacial Water Driven by Hydrogen Bond Fluctuations. J. Phys. Chem. B 2014, 118, 1861-1866.

(55) Kinugawa, T.; Enami, S.; Yabushita, A.; Kawasaki, M.; Hoffmann, M. R.; Colussi, A. J. Conversion of gaseous nitrogen dioxide to nitrate and nitrite on aqueous surfactants. Phys. Chem. Chem. Phys. 2011, 13, 5144-5149.

(56) Enami, S.; Mishra, H.; Hoffmann, M. R.; Colussi, A. J. Hofmeister effects in micromolar electrolyte solutions. J. Chem. Phys. 2012, 136, 154707.

(57) Ingram, A. J.; Boeser, C. L.; Zare, R. N. Going beyond electrospray: mass spectrometric studies of chemical reactions in and on liquids. Chem. Sci. 2016, 7, 39-55.

(58) Laskin, J.; Laskin, A.; Nizkorodov, S. A. New mass spectrometry techniques for studying physical chemistry of atmospheric heterogeneous processes. Int. Rev. Phys. Chem. 2013, 32, 128-170.

(59) Davidovits, P.; Kolb, C. E.; Williams, L. R.; Jayne, J. T.; Worsnop, D. R. Update 1 of: Mass Accommodation and Chemical Reactions at Gas-Liquid Interfaces. Chem. Rev. 2011, 111, PR76-PR109.

(60) George, I. J.; Abbatt, J. P. D. Heterogeneous oxidation of atmospheric aerosol particles by gas-phase radicals. Nat. Chem. 2010, 2, $713-722$.

(61) Chapleski, R. C.; Zhang, Y.; Troya, D.; Morris, J. R. Heterogeneous chemistry and reaction dynamics of the atmospheric oxidants, $\mathrm{O}_{3}, \mathrm{NO}_{3}$, and $\mathrm{OH}$, on organic surfaces. Chem. Soc. Rev. 2016, 10.1039/C5CS00375J.

(62) Atkinson, R.; Baulch, D. L.; Cox, R. A.; Crowley, J. N.; Hampson, R. F.; Hynes, R. G.; Jenkin, M. E.; Rossi, M. J.; Troe, J. Evaluated kinetic and photochemical data for atmospheric chemistry: Volume I - gas phase reactions of $\mathrm{O}_{x}, \mathrm{HO}_{x}, \mathrm{NO}_{\mathrm{x}}$ and $\mathrm{SO}_{\mathrm{x}}$ species. Atmos. Chem. Phys. 2004, 4, 1461-1738. 
(63) Roeselova, M.; Vieceli, J.; Dang, L. X.; Garrett, B. C.; Tobias, D. J. Hydroxyl radical at the air-water interface. J. Am. Chem. Soc. 2004, 126, 16308-16309.

(64) Bagot, P. A. J.; Waring, C.; Costen, M. L.; McKendrick, K. G. Dynamics of inelastic scattering of $\mathrm{OH}$ radicals from reactive and inert liquid surfaces. J. Phys. Chem. C 2008, 112, 10868-10877.

(65) Vacha, R.; Slavicek, P.; Mucha, M.; Finlayson-Pitts, B. J.; Jungwirth, P. Adsorption of atmospherically relevant gases at the air/ water interface: Free energy profiles of aqueous solvation of $\mathrm{N}_{2}, \mathrm{O}_{2}, \mathrm{O}_{3}$, $\mathrm{OH}, \mathrm{H}_{2} \mathrm{O}, \mathrm{HO}_{2}$, and $\mathrm{H}_{2} \mathrm{O}_{2}$. J. Phys. Chem. A 2004, 108, 11573-11579.

(66) Bardouki, H.; da Rosa, M. B.; Mihalopoulos, N.; Palm, W. U.; Zetzsch, C. Kinetics and mechanism of the oxidation of dimethylsulfoxide (DMSO) and methanesulfinate ( $\left.\mathrm{MSI}^{-}\right)$by $\mathrm{OH}$ radicals in aqueous medium. Atmos. Environ. 2002, 36, 4627-4634.

(67) Osada, K.; Hayashi, M.; Shiobara, M.; Hara, K.; Wada, M.; Hashida, G.; Morimoto, S.; Yabuki, M.; Yamanouchi, T. Atmospheric observation room for clean air at Syowa Station, East Antarctica. Antarctic Rec. 2006, 50, 86-102.

(68) Hara, K.; Osada, K.; Kido, M.; Hayashi, M.; Matsunaga, K.; Iwasaka, Y.; Yamanouchi, T.; Hashida, G.; Fukatsu, T. Chemistry of seasalt particles and inorganic halogen species in Antarctic regions: Compositional differences between coastal and inland stations. J. Geophys. Res. Atmos. 2004, 109, .

(69) Hara, K.; Osada, K.; Yabuki, M.; Yamanouchi, T. Seasonal variation of fractionated sea-salt particles on the Antarctic coast. Geophys. Res. Lett. 2012, 39, L18801.

(70) Pryor, W. A.; Giamalva, D. H.; Church, D. F. Kinetics of ozonation 2. amino-acids and model compounds in water and comparisons to rates in nonpolar-solvents. J. Am. Chem. Soc. 1984, 106, 7094-7100.

(71) Lee, Y. N.; Zhou, X. L. Aqueous reaction-kinetics of ozone and dimethylsulfide and its atmospheric implications. J. Geophys. Res. 1994, 99, 3597-3605.

(72) Gershenzon, M.; Davidovits, P.; Jayne, J. T.; Kolb, C. E.; Worsnop, D. R. Simultaneous uptake of DMS and ozone on water. J. Phys. Chem. A 2001, 105, 7031-7036.

(73) Enami, S.; Hoffmann, M. R.; Colussi, A. J. Ozone Oxidizes Glutathione to a Sulfonic Acid. Chem. Res. Toxicol. 2009, 22, 35-40.

(74) Enami, S.; Hoffmann, M. R.; Colussi, A. J. How phenol and alphatocopherol react with ambient ozone at gas/liquid interfaces. J. Phys. Chem. A 2009, 113, 7002-7010.

(75) Enami, S.; Hoffmann, M. R.; Colussi, A. J. Simultaneous detection of cysteine sulfenate, sulfinate, and sulfonate during cysteine interfacial ozonolysis. J. Phys. Chem. B 2009, 113, 9356-9358.

(76) Enami, S.; Hoffmann, M. R.; Colussi, A. J. Ozonolysis of uric acid at the air/water interface. J. Phys. Chem. B 2008, 112, 4153-4156.

(77) Donaldson, D. J.; Valsaraj, K. T. Adsorption and reaction of trace gas-phase organic compounds on atmospheric water film surfaces: A critical review. Environ. Sci. Technol. 2010, 44, 865-873.

(78) Finlayson-Pitts, B. J. Reactions at surfaces in the atmosphere: integration of experiments and theory as necessary (but not necessarily sufficient) for predicting the physical chemistry of aerosols. Phys. Chem. Chem. Phys. 2009, 11, 7760-7779.

(79) Sorensen, S.; Falbe-Hansen, H.; Mangoni, M.; Hjorth, J.; Jensen, N. R. Observation of DMSO and $\mathrm{CH}_{3} \mathrm{~S}(\mathrm{O}) \mathrm{OH}$ from the gas phase reaction between DMS and OH. J. Atmos. Chem. 1996, 24, 299-315.

(80) Urbanski, S. P.; Stickel, R. E.; Wine, P. H. Mechanistic and kinetic study of the gas-phase reaction of hydroxyl radical with dimethyl sulfoxide. J. Phys. Chem. A 1998, 102, 10522-10529.

(81) Hynes, A. J.; Wine, P. H. The atmospheric chemistry of dimethylsulfoxide (DMSO) and mechanism of the OH+DMSO reaction. J. Atmos. Chem. 1996, 24, 23-37.

(82) Bock, H.; Solouki, B. Photoelectron spectra and molecular properties. 9. sulfoxide bond. Angew. Chem., Int. Ed. Engl. 1972, 11, 436438.

(83) Wang, L. M.; Zhang, J. S. Ab initio study of reaction of dimethyl sulfoxide (DMSO) with OH radical. Chem. Phys. Lett. 2002, 356, 490496.
(84) Gilbert, B. C.; Norman, R. O. C.; Sealy, R. C. Electron-spin resonance studies. Part XLIII. reaction of dimethyl-sulfoxide with hydroxyl radical. J. Chem. Soc., Perkin Trans. 2 1975, 303-308.

(85) Borin, I. A.; Skaf, M. S. Molecular association between water and dimethyl sulfoxide in solution: A molecular dynamics simulation study. J. Chem. Phys. 1999, 110, 6412-6420.

(86) Enami, S.; Vecitis, C. D.; Cheng, J.; Hoffmann, M. R.; Colussi, A. J Mass spectrometry of interfacial layers during fast aqueous aerosol/ ozone gas reactions of atmospheric interest. Chem. Phys. Lett. 2008, 455, 316-320.

(87) Vieceli, J.; Roeselova, M.; Potter, N.; Dang, L. X.; Garrett, B. C.; Tobias, D. J. Molecular dynamics simulations of atmospheric oxidants at the air-water interface: Solvation and accommodation of $\mathrm{OH}$ and $\mathrm{O}_{3} . J$. Phys. Chem. B 2005, 109, 15876-15892.

(88) Roeselova, M.; Jungwirth, P.; Tobias, D. J.; Gerber, R. B. Impact, trapping, and accommodation of hydroxyl radical and ozone at aqueous salt aerosol surfaces. A molecular dynamics study. J. Phys. Chem. B 2003, 107, 12690-12699.

(89) Enami, S.; Hoffmann, M. R.; Colussi, A. J. OH-Radical Specific Addition to Glutathione S-Atom at the Air-Water Interface: Relevance to the Redox Balance of the Lung Epithelial Lining Fluid. J. Phys. Chem. Lett. 2015, 6, 3935-3943.

(90) Kameel, F. R.; Riboni, F.; Hoffmann, M. R.; Colussi, A. J. OH Radical-Initiated Chemistry of Isoprene in Aqueous Media. Atmospheric Implications. J. Phys. Chem. A 2013, 117, 5117-5123.

(91) Faloona, I. Sulfur processing in the marine atmospheric boundary layer: A review and critical assessment of modeling uncertainties. Atmos. Environ. 2009, 43, 2841-2854.

(92) Stone, D.; Whalley, L. K.; Heard, D. E. Tropospheric OH and $\mathrm{HO}_{2}$ radicals: field measurements and model comparisons. Chem. Soc. Rev. 2012, 41, 6348-6404.

(93) Hara, K.; Osada, K.; Nishita-Hara, C.; Yamanouchi, T. Seasonal variations and vertical features of aerosol particles in the Antarctic troposphere. Atmos. Chem. Phys. 2011, 11, 5471-5484.

(94) Quinn, P. K.; Bates, T. S. The case against climate regulation via oceanic phytoplankton sulphur emissions. Nature 2011, 480, 51-56.

\section{NOTE ADDED AFTER ASAP PUBLICATION}

This paper was published ASAP on January 28, 2016 with partial corrections applied due to production error. The corrected paper was reposted on February 2, 2016. 